\title{
Arte-hezkuntzaren kezkak eta arazoak gizarteko kultur entretenigarritasunetik haratago. Eskulturak baimentzen digun ikuskeraren ekarpena unibertsitateko irakaskuntzan
}

\author{
Isusko Vivas Ziarrusta \\ Amaia Lekerikabeaskoa Gaztañaga \\ Eskultura Saila \\ Arte Ederren Fakultatea \\ Euskal Herriko Unibertsitatea UPV/EHU
}

DOI: $10.1387 / \tan$ tak.17485

GAKO-HITZAK: goi mailako arte-hezkuntza, arte garaikidea, arte plastikoak, eskultura, metodologia, unibertsitate-sistema.

Zergatik ote dira aurren zirriborroak hain pintura berrien antzekoak? Ederki dago galdera: haurren zirriborroak dira zenbait pintura berrien antza dutenak eta ez alderantziz. Pintura kaxkarrek, berriz, axaleko fotografiaren kopiak dirudite. Egiazko artistak ez baitira kopiatzen ari, ezta haurra ere. (Oteiza, 2007: z/g)

\section{GATAZKAREN IDENTIFIKAZIO KONPLEXU BAIZEN ANGELUTSUA DELA ETA; GEOGRAFIA EZAGUNETARA SARRERA}

Arazoak eta gatazkak ez dira batere baliagarriak, helburu baten ilusioa sortzen duten baloreak baino ez dituzte errepresentatzen eta. (Smithson, 2009: 17)

Larritasuna beti izan omen da artista amorratuaren patua, eta haren izana bezainbat izena ere iragartzeko sintoma. Egunsentiko lurrinaren pean, Friedrich margolariaren fraide bakartiak urrutiko ortzi-muga hodeitsuaren pisua gertuegi sumatzen zuen gisan, egoera aferatsuak aspaldidanik 
izan dira arte modernoaren gakorik behinenak; malkoz malko, gauean sublimaturiko ur kondentsatuaren tantak, garoa fin goiztiarrarenak, laino zuri potoloarenak, negarrarenak edota kemenaren berotasunean isuritako izerdi hotzarenak diren erraztasunez nabaritu ezinean. Hala nola, 'moderno' izenaz 'garaikide' kontzeptua erabil daiteke artearen arloko pentsamenduan. Friedrich eta bere garaiko batzuk izan ohi ziren lehenengoetariko 'modernoak', hitz horrekin aro historikoa baino une jakin baten burutazioak dabiltzala, batez ere, honako gogoetaren baitan.

Burutazioak bitarteko, antzinatasunera zein erdi aroko bihurguneetara doan atzerako bidean gehiegi sakondu baga, artearen funtzio magiko/mistikoaren txinparta pedagogikoa ere bazen modu batean edo bestean. Hori baino lehenago aitzin gizakiaren begiradaz paisaia bihurtu zen lurraldetasunean hastapeneko harridura estetikoa topatu dute batzuk, mesfidantza puntu batez bada ere. 'Proto-heziketaren' nahiak, harrezkero, gailendu izan dira artea kultura jakin bateko botere politiko, ekonomiko, izpiritualen pentsuan azpiratu izan den guztietan, eta betebehar didaktiko/teologikoaren erpinik gorena seguruenik erdi aroko mendeetan ez ezik harrietan ere balegoke; erliebea eta eskultura arkitekturarekin hartu-eman estuan herriari izpirituzko segurtasun eztabaidaezinak eta ukaezinak sugarretan irmoturik eskaintzeko asmotan. Beranduago, lozorroaren iratzarpenak berpizkundeko ateetan, giza harremanen eta paisaiaren bestelako ulerpenak ekarriko zituen, arras burgesagoak baina horiek ere gizarte konkretuen erakusgarriak. Paisaia jauregitxoko leihatilatik ikuskatzen zen 'pintura' karratua edo laukizuzena baitzen. Geroago,, arkitekturak artearen esparrutik kale egin zuen bere izate autonomoa aldarrikatuz eta horrekin, diziplina desberdinen banaketan oinarritzen ziren hezkuntza-sistema akademiko propioak apurka egonkortuz. Denborazko saltoak bidenabar, hori une honetan gutxiago dagokigun istorioa litzateke.

Gaurko egunetan, aldiz, gizarteko sektore dirudun-boteretsuen eta bestelako klaseen arteko etendura murriztu ordez alderantzizko proportzionaltasunez luzatuz doan heinean, mundua feudalismo gaurkotuaren fasean murgildu dela esango dute bai Luis Camnitzerrek (2013) artearen jesarlekutik eta baita kulturaren aferetan diharduten beste autore zenbaitek ere (oraintsu zendutako Umberto Eco filosofo eta semiologian trebatuak, besteak beste). Batik bat ekonomikoki erroturiko botere lodi horiek, gainera, euren 'hiperfondoak' erabiltzea aukeratzen badute kultura kontrolatzeko, hori da hain zuzen erdi aroan geneukan panorama (Camnitzer, 2013). Izan ere, mundu-mailako globalizazioaren fondo ekonomikoei men egiten dieten 'diktadura' sasi demokratiko gehienetan artea ez da izaten jadanik kultura eztabaidatzeko ezta bere gabeziak zein kontrakotasunak argitan jartzeko tresna, dagoenaren ospakizuna baino. Horixe litzateke, alegia, $\mathrm{xx}$. mendeko lehen erdialdeko gerrate eta holokaustoen galdera erretorikoetatik eratorria. Zein neurritan balio du arteak kontzientziak sumintzeko eta sentsibilitateak laztantzeko? Abangoardia garaiaren muinoan, Federico 
Fellini zinegileak argiro erakutsi zuen arteak ez zituela basatikeriak samurtzen, eta gogoeta horretatik ere ondoriozta daiteke arteak baimentzen duen sentiberatasun kontziente edota inkontzientea beste plano batetan aurkitu beharko litzatekela: iheskorragoa, identifikatzeko gaitzagoa, hauskorra eta maiz oldarkorra. Ohiko lengoaiez bestaldean, proposamen plastikoak beraien materialtasunean ematen dira baina mundu ezezagunak irekitzen dituzte gizakion adimenaren aurrean. Postmodernitatearen ondorengo gizarte berrietan ostera ere galdegiten zaio norberaren buruari artearen funtsaz eta artearen lekuaz (Camnitzer, 2013); guda-tokiak orain ere han-hemenka oparo izan badirenean (beharbada zuzenki ikusi ezin direnak) eta egoera horiek anplifikatzen dituzten beste eraso kultural, ekonomiko eta politiko ikusgai nahiz ikusezinen menpeko gizarteetan.

Alde batetik, geografia 'ezagun' horiek proposamen honetan batez ere Euskal Herriko Unibertsitateko (UPV/EHU) Arte Ederren Fakultateko paretak, aretoak, ikasgelak eta lan-tailerrak izango dira euskarri legez erabiliak. Bertzetik, kontzeptuzko 'geografia' ezagunak bertan eguneroko 'ogia' den artearen irakaskuntzako moldeak, aferak eta erronkak izango dira. Txit aldakorrak, sedimentazioz metaturiko goi-geruzetan bada ere, ia hamarkada eta erdiko esperientzian arte-hezkuntzaren teoria orokorretatik ${ }^{1}$ eskulturaren alor berezituko trebakuntzara iraganean nozitu, eskertu zein aldizka sufritu izan direnak. Bertan, galdera ikurrak bere materialtasunean atzematen dira, sentiberatasun eta emozio estetikoaz ${ }^{2}$, objektuek (materialak) espazioan eta beraien artean duten artikulazioan. Eskultura alorreko irakaskuntza-esperientzia batzuk adibide eta eztabaidagai izango dira, bertan murgilduriko unibertsitate-sistema maiz kontraesankorraren aldaketa zinez bortitzak (bere kanpo-itxuran eta ikusi beharko barne-izaeran) mundu mailako markoetatik barra-barra heltzen diren honetan. Lehenik paradigma akademiko zahar edota eraberrituetan jarriko da arreta; batzuk aipatu egunerokotasuna zipriztintzen dutenak eta beste zenbait irauliak izan direnak, geroago eskulturaren praxiaren betaurrekoekin ikusiriko 'paisaiak' idazki honetara erakartzeko gurariaz. Hau izango da testuaren muina eta hemendik abiatuta etorkizuneko bideak, bidezidorrak eta hauen saihesbideak identifikatzeko gaitasunak frogatua beharko luke, inguratzen gaituen anabasa 'gogor-malguan'.

${ }^{1}$ Duela hamar bat urte hezkuntzaren etapa desberdinetako arte-irakaskuntzari eta baita arte-heziketa unibertsalagoari zuzendutako ikerketa-testu bat argitaratu zen gaiari eskainitako aldizkari zientifiko honetan (Vivas, 2007: 81-134). Haren oihartzuna ez dadila ahantzi eta oraingoan ikusiko da nola unibertsitate esparruko gainontzeko esperientzian, alderdi teoriko batzuk erresonantzia kutxan bezala belarriratzen diren, haren usaia ere sudurrean sentituz.

2 Ohartu behar da ez dela hemen erabiltzen 'estetika' kategoria artearen filosofia gisa, baizik artearen praxitik datorren zentzu 'estetikoa' da aldarrikatzen dena. 


\section{PARADIGMA AKADEMIKO ZENBAIT, ONARTUAK EDOTA IRAULIAK, UNIBERTSITATEKO ARTE-IRAKASKUNTZA AKADEMIKOAREN EGUNEROKOTASUNEAN TXERTATURIK; ARTEA TRANSMITITZEAREN HAUSNARKETAZ MINTZO}

Berriki egokituriko Europako politikek, Boloniako planak bezalaxe, unibertsitate erraldoietan biltzen diren jakintza espezializatuak hobetsiz herrialdez-herrialdeko jakituriaren toki ertain eta txikiagoen desagerpena eragiten edo areagotzen dute. (Gamarra, 2012: 103)

L. Camnitzer aipatu autoreak (Didáctica de la Liberación liburuaren edizio berria dela eta eskainitako elkarrizketan) halako zer edo zer dio. Artea nolabait kultura bera (esfera orokor horren parte izanik ere) asaldatzeko eta nola edo ahala 'gaindi' egiteko legoke, jakintza sentikor baten aurkikuntzan. Alabaina, aldaketaren efektu legez eta aldaketak hori modu 'progresista' batean aurrera egiteko bada (eta honetan datza, alegia, Camnitzerren ikuspegi positibista), autorearentzat egitasmo kultural bezala interes handiagokoa litzateke hezkuntza sistemaren gorabeherak aldatzea edo eraldatzea artelan bat paretan kokatzea baino, apika ustezko efektibotasun kulturalaren mesedetan.

Halere, modu batean edo bestean; erdi aroko gremioetan, berpizkundeko Akademian (hizki larritan), artista-tailer modernoetan, arte aplikatuen zein ofizio artistikoen eskola garaikideetan, eta asma daitezkeen ezein moldeetan helburua arte-hezkuntza garaian garaiko heziketa tekniko, zientifiko, profesional, artistiko nahiz humanistikoen paradigma orokorragoetan kokatzea izan da; gaur egun goi mailako irakaskuntzan (unibertsitate-sistema edota homologatua). Horrela curriculum akademikoak nola edo ahala parekidetu ahal izateko eta ikaskuntza prozesu konplexuak kuantifikatzeko esfortzuarekin. Baliokidetza horiek berritsu pasa behar dute, derrigor, Boloniako akordioetan ezarri ziren estutasunetatik baina betidanik izan dira merkatuaren mugek zein dinamikek finkaturiko korapiloetan nahasiak, egitura politiko ekonomikoekin dantzan. Modeloen zabalkuntza eta esportazio gero eta nabarmenagoak, oro har, tokian tokiko ezberdintasunak txikitzera jotzen du; geroz eta modelo globalago horiek apenas kontuan hartzen dutelarik ezagutzen transmisioa gertatzen den ingurunearen eta kultura propioetan euskarrituak dauden 'eskola' ereduen sena. Kakotx artean idatziriko 'artista' (hala deitu badaiteke behintzat) anitzen 'harremana' sustatzeaz gain (adin eta esperientzia maila askotarikoak), adituek oraindik orain ez dute batere argi ikusten arte-eskoletan gerta daitekeen transmisio prozesua 'irakaskuntza-ikaskuntza' izendatu daitekeen ere; ez baitira gutxi artea 'irakastea' posible ez delako ideia mantentzen duten artista 'irakasleak'. Honek guztiak, izatez, aurrekari argiak ditu. 
Aurrekari horien artean leudeke hezkuntza-eredu konkretuen bitartez taiuturiko 'artistaren' edo 'artegilearen' rolaz beraien premisak sostengatzen dituzten paradigmak. Direlako paradigmak, era berean, beste axioma zenbaiten aldamenean egituratzen dira. Goian aipatua, letra larriekin idatziriko garai bateko Akademiaren itzala izan daiteke horietako bat. Akademiatik $^{3}$ ateratzen den 'artista' ikasia eta tradizioz artea definitu duten teknika zein prozeduren menperatzailea da. Ikasketa 'luze' eta etengabekoaren ostean bilakatu daiteke norbait 'artista' (Sauras, 2006). 'Maisuak' atzetik datozen ikasleei bere aitzinean zeuden beste batzuen testigua helarazten die. Hau da, jakintza herentziaz jasoa du eta aldi berean transmisioaren izpia ebaki ordez posible egiten du.

Gremioen eta artisauen lekukotza sumatu daiteke bere erroetan baina bestalde, abangoardia historikoen artea irakasteko modua ere, distantziak salbu, nola edo hala lerrokadura honetan identifika daiteke, modernitatearen utopia arrazional eta ortodoxoak predikatu zuen arteen sinkretismotik ez oso urruti, kasurako abangoardiako artisten makina bat idazki eta manifestutan nabarmendu datekeenez (González; Calvo Serraller \& Marchan Fiz, 1979). Tailerreko praktikan oinarritzen den sistema honetan irakasleek euren jakintza transmititzen zieten/diete ikasleei. Luzaroan Frantziako École des Beaux-Arts delako erakunde adierazgarriak defendatu izan duena eta oraindik ere Europako herrialde batzuetako eskolek, espainiar estatuko fakultateek besteak beste (San Fernando, San Luis edo San Carlos bezalako Akademien familia-kide 'urrunak') mantentzen dutena, baina aldatzeko zorian legokeena. Fakultate eta goi-eskola hauetan guztietan geroz eta gainbegiratze ozenagoa dute irakaskuntzaren kudeatzaile teknokratek eta politikaz gaindiko super-egitura ekonomikoek, aspaldiko intelektualtasunaren eta 'akademikoen' ordez. Beraz, erakunde horien modu operatiboak eta (arte) hezkuntza bera modernitatearen ondorengo egoeran eraldatze bidean daude. 'Diziplina' desberdinen sailkapena zailtasunez atzeman daiteke dagoeneko, berezitasunak (espezialitateak) ezabatuz joan direlarik azkeneko hamarraldietan. Batez ere espainiar estatuko ia fakultate guztiak hezkuntza sistema publikoan murgildurik, heziketaren kostua prezio publikoek ezartzen dute ${ }^{4}$.

${ }^{3}$ Unibertsitate-sistema gaurkotuek jakina da 'Akademia' terminoaz imajina daitekeen oinarri historiko hartatik gutxi dutela jada. Hala ere, unibertsitate-sistema bera 'akademikoa' deitu izan denez, hitz hori erabiliko da modernitatean berreskuratutako lekukotasun historikoaren seinale oparo gisa.

${ }^{4}$ Frantziako Système Supérieure adibidez doakoa eta 'garantista' da; horretaz aparte, ikasle gehienek diru-sariak eskuratzen dituzte garraiorako ez eze ekoizpenaren gastuetan partzialki laguntzeko. 


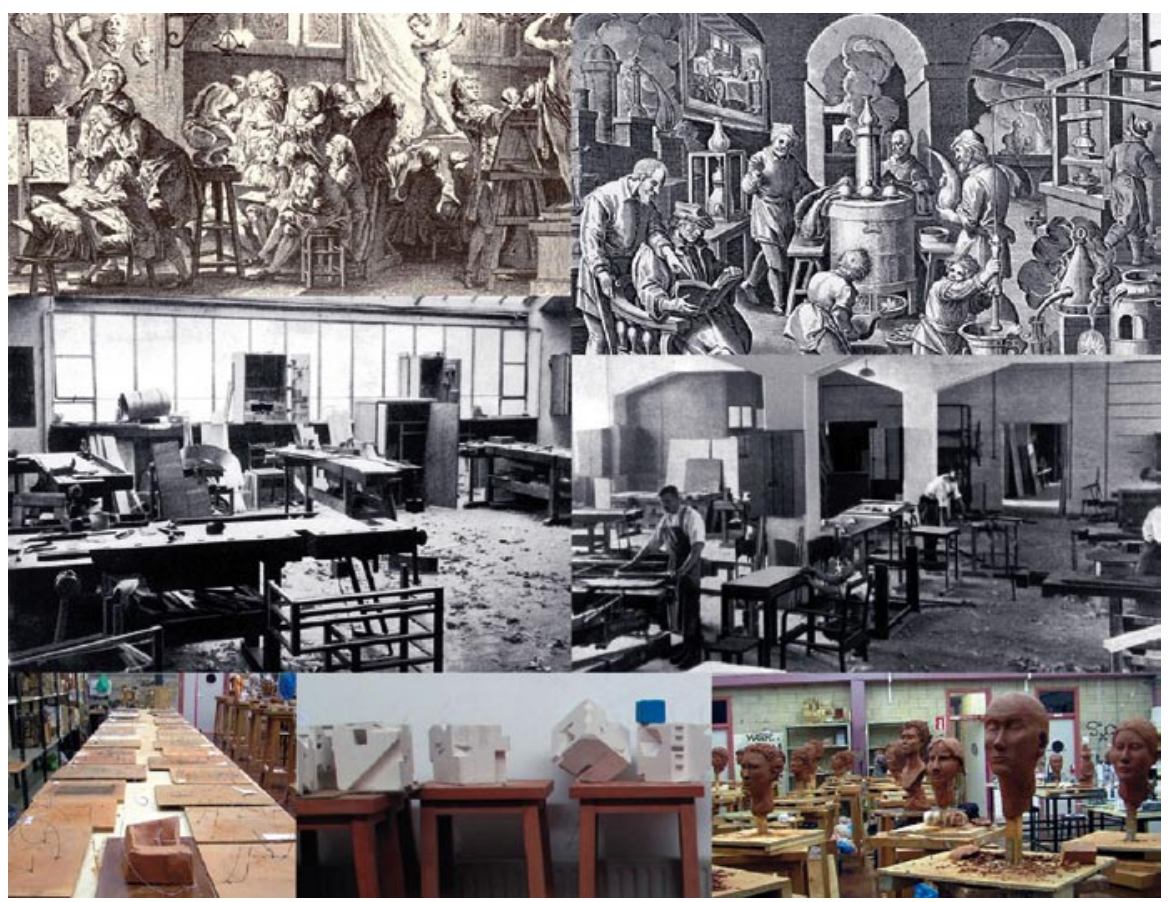

1. irudia

(goitik behera) XVI eta XVII. mendeko eskultura-tailerra, Bauhaus eskolako ikasgelak (sarean) eta Arte Ederren Fakultateko modelatu, hustuketa eta eraikuntza gelak (2007-2008. urtea)

Hurrengo paradigma baten eta asko laburbilduz, auto-espresio edo autoadierazpen sortzailea legoke. 'Artista' izatearen sena norberaren garapen pertsonalean datza eta norbera da, hein handian, bakoitzaren abilezia eta ahulezien kontzientzia hartzen duena. Pertsona guztiek espresatzeko ahalmena, baimena eta beharra dutenez, indar hori teknika 'artistikoak' erabiliz iratzartzea posible eta zilegi da. Batez ere psikologiako ideia hauek (Lowenfeld, 2008) ( $^{5}$ arte-hezkuntza 'berriak' berreskuratuko zituenez, II. Mundu Gerratearen ondorengo artearen giroan, XX. mendeko 50. hamarkadako espresionismo abstraktuaren sasi-iraultzaren magalean gailendu eta arte-hezkuntzan eragin iragankorra izango zuten. Beluago, xx. mendeko 70. hamarkadatik 80. hamarkada bitarteko goi-hezkuntza artistikoaren planeamenduetan isla edukiko zuen berriro, heziketa artistiko formala goi-es-

\footnotetext{
${ }^{5}$ Haurren eboluzio grafikoaren etapak eta abar ikertu zituzten, baina haien eragina ez zen soil-soilik umeengan edo hauei zuzenduko arte-hezkuntzaren teorietan geldituko, ordutik aurrera barreiatuz.
} 
koletatik unibertsitate-fakultateetara saltoa egiteko garaiarekin kointzidente izanda, testuinguru definituan batik bat. XXI. gizaldira hurbildu ahala, beharbada espresioaren alderdi 'materialak' nola edo hala izpirituzko janzkera ponposoagoa bereganatuko zuen une batzuetan, horrela esan badaiteke.

Gaur egun aldiz, subjektibotasuna noizbait kuantifikagarria bilakatu daitekeen zerbait izatera heltzea kontsideratu dezakeen korrontea (Echevarría, 2011) arteen irakaskuntzaren eta berauen aldikako erreformen aspekturik polemikoenetakoa izatera iritzi da; bai graduetan eta hauen homologazioan; baita gizarteko aktibitate gisara ere. Honi loturik, arte ederren eskola eta fakultateetan disfuntzio produktiboaren zenbait 'askatasun' gune eratzeko potentziala existitu izan da (Brown, 2011). Zona horietan gauzak, beharbada, ez dira ohiko eran 'gustiz' ulergarriak izaten ezta 'argitasun' osoz kodigo ezagunetara formateaturik erakartzen. Alabaina, espazio horietan arrisku handiak ere baleudeke; zeren eta potoloegia baita espazio horiek kontrolatzeko, kuantifikatzeko eta neurtzeko nahia. Boloniako planarekin, gestoreek irakaskuntzan orokorki zeresan nabarmenagoa izan dutenean (negozioen esferan gertatzen den bezala), ondoeza nabaritzen da esandako leku horien inguruan eta beraien antolaketa zein funtzionamendu baldintzetan. 'Bitarteko' espazioak alegia, zirrikituak, pentsamenduaren askatasunerako apustua mantentzeaz gain, artearen kasuan 'etendura' narratiboa balioetsi beharko luketenak, nahiz eta kasu askotan erakundeetan txertaturik bizirauten duten. Izan ere, kontrolaren mekanismoak sarri askotan ez ditu kanpoko begi orojakile batek modu zuzenean irradiatzen baizik eta irakasle edota langileak deituak izaten dira beraien eguneroko egitekoaren 'gehigarriak' diren paperak betetzera. Horien artean legoke gainontzeko lankideak eta ikasleak kontrolatzea (Browm, 2001), zehar-lerro 'ofizialetatik' gauzak ez daitezen erabat okertu. Noiz dira, hortaz, aplikatzen diren egitura pedagogiko didaktikoak doktrina konkretuen ardatz-zuzentzaileak, estruktura ideologikoen mantenua posible egiten dutenak? Barrenean, gida-lerro horietatik aldentzen denak behar den moduan transmititua izan ez den informazioaz joka dezake. Eta horrek esan nahi du, hain zuzen, kapitalismo korporatiboaren ideiari ez zaiola egokiro heldu eta nonbait zabalkunderako oztoporen bat edo beste aurkitu duela; kontziente edo inkontzienteki. Ustezko 'hanka-sartze' horien emaitzak esandako mekanismo politiko ideologikoak aldrebesten ditu eta ondorioz, finantziazio-iturriak ukatzen/ murrizten (hau ere kontzienteki edota inkontzienteki).

Gauzak honela, aurreko paragrafoaren hastapeneko paradigmak laster hartuko zuten ikus kulturaren interpretazioaren aldeko bidea. 'Artista' izateak edo ez-izateak ez du hainbeste inporta, baizik hainbat errekurtsoren jabe izatea litzateke gakoa, irudiez bete-betea eskaintzen zaigun kultura orokorrean diskurtso interpretatzaile kritikoak ulertu arazteko (Hernández, 2002; Agirre, 2002). Irudien fikziozko planeta birtualean, 'faltsua' 'egiazkoarekin' nola korapilatzen den ongi igarri daiteke. Xx. mendeko azkenaldiko 90. hamarkada sartuta, arte-hezkuntza formalaren berrikuspenek jakintza arloaren 
berregituraketak baimendutako bektoreen norabide petoak trazatuko zituzten. Ikono-esfera deiturikoa ulertzeko alderdi honek oihartzun bizkorragoa lortuko zuen, lehenengo instanteetan, Ipar Ameriketako Estatu Batuetako hezkuntza-sisteman, xx. mendeko 60-70. hamarkadetatik ikusgarri zegoen kontzeptuzko arte diskurtsiboen bidelagun. 'Multi-inter-trans-pluri' aurrizkiak darabiltzan diziplinartekotasun goiztiarra ere aldarrikatu zuten modelo berritzaile gisa, batez ere artearen eta diseinuaren uztarketaz. Uztartze hori 'sinkretikoa' baino (hau da, abangoardien tradizio historikoak posible egindako arteen sintesian baino - Bauhaus eskolaren guraria, alegia-), ibilbide komertzialago eta 'apaingarriagoak' hornitu zuenaren susmoa zegoen. Bestalde, sistema hau batez ere pribatua da; maiz ikasleek beraien gain hartu behar dute prozesu osoaren sama ekonomiko astuna. Kontrakotasuna dirudien arren, barau ez da Boloniako itunetara egokitzen baina, aitzitik, Boloniaz geroko aldaerak honetan euskarritzen dira nagusiki ${ }^{6}$. Hiru ikuspegi hauen elkarkidetza iradokitzen da unibertsitate-asmoen erdian.

Izate artistikoa bere horretan neurtzea (eta noski, beroni loturik arte plastikoen irakaskuntza eta ebaluazioa) bere aspektu kualitatibo, aztoratzeko gaitz diren idealei gehiegi ukitu baga, dirudiena baino sinpleagoa suertatu daitekeela defendatuko dute batzuk (Echevarría, 2011). Honetarako bi neurri mota bereiztu beharko lirateke, alegia; irakaskuntzaren egoera erreala detektatzen duena bata eta mundu soziala 'eskaneatzen' duena bestea': neurri 'bitartekaria' nolabait esanda. Egikera hauek beste prozedura kuantifikatzaile batzuk ere badaudela erakutsiko dute, konparaziorako segun zein 'neurri', 'estadistika' eta 'juizio-intuizio' bermatzen den.

Honela bada, Boloniako kezkak piztu zirenetik hamarkada osoa iraganda, data horrek arte-irakaskuntzaren amaiera ${ }^{8}$ ekarriko zuela uste izan zen, honaino ezagutu ziren 'askatasun' baldintzetan bederen. Orduraino kasik inortxori ez zitzaion axola zer demontre gertatzen zen arte-hezkuntzako erakunde baten barnean, jantzi 'akademikoak' berritu eta garbitu zituzten arte. Erreforma horiekiko lehen erreakzioa inbasio baten aurreko

\footnotetext{
${ }^{6}$ Sistema Kanadarra, zeina ez dugun hurbiletik ezagutzen, hauen hiruren nahasketa antzekoa omen da, eta Tony Browm ikerlariaren esanetan justuagoa.

${ }^{7}$ Noiz edo noiz José Ortega y Gasset maisu-pentsalari eta filosofoak esaten zuena datorkigu burura: «saminez bizi ditugun garaiotan, unean-uneko adierazgarriena da 'arima' sinpleak, sinple izaten jarraitzeko exijitzen duen eskubidea, eta gainera edonon inposatzen duena» (La rebelión de las masas).

8 Aldika-aldika jaiotzen dira garrantzizko zerbaiten 'amaiera' ekarriko duten joera sasi katastrofistak. Garaian garaiko korronteen testigu, 'munduaren' amaiera alde batera utzita izan dira historiaren 'amaieraz', gizartearen 'amaieraz' eta artearen 'amaieraz' (Arhur C. Danto, adibidez) hainbat aurreikuspen. Akabuko muga horretatik aurrera, aldiz, bai munduak, gizarteak, historiak edota arteak jarraipena duela ikusi da. Beste gauza bat litzateke, noski, jarraipen eta garapen hori nolakoa den, baina honakoa betiko kontu berbera gogoratzea baino ez da; bai egituren nolabaiteko errepikapenarekin (estrukturalismoaz arituz) edota historiaren jarraikortasunarekin (materialismo historikoa).
} 
defentsa sutsu bezain itsua izan bazen ere, G. Echevarríak dio antolaketa horren zenbait alderdi goi-hezkuntza artistikoa berriz zentratzeko onuragarriak izatera helduko zirela: erritmoak, denboraltasuna, arteko seminarioak ohiko tailerrez aparte, e. a. Horien artean ebaluazioaren garrantzia; autoespresio sortzaileari atxikitako ereduetan amorruz gaitzetsia izan ziekeen praktika, bokazio publikoaren mesedetan kritikako elementu baliagarri bat bere benetako dimentsioan berrezarri duena. Adierazpen hauen aurrean baina, zer da ebaluatzen dena? Objektua hala jarrera? Emaitza hala prozesua? Trebetasuna hala kontzeptu-hausnarketa?

Pentsalari hauentzako bestelako abantaila eta desabantailen artean, artistek lan eginez ikasten duten tailerretan sortu den arte kritikarako eta teoriarako joeraren bizkortzea eta birkokatzea legoke, artistek beraiek bideratzen dutena. Txarrena litzateke aldaketa berri hauek dakarten egokitzapena arteekoizpenaren eta produkzio beraren artean (atzizki edo adjektiborik gabekoa), diziplina guztietan ekibalentzia edo baliokidetza duena. Halako ekintzek arteekoizpena azken finean aberastasunaren produkzioari bateratzen diote; produktu nozio berak 'proiektu' kontzeptuarekin konbinaketan bizitza osoa amaigabeko merkatu-prozesuan transformatzen duelarik. Eta arte sorkuntzak ez du funtzionatzen bakarrik gizarteari eskaintzen dizkion kontsumo produktuekin ezta bere izaera gorpuztu dadin behar dituen beste material eta lehengaiekin, baizik hausnarketa sendora dedikatzeko prestatu behar duen denbora-tarteekin eta gogoeta, ikasketa mardul zein burutapenetarako abaguneekin.

\section{ESKULTURATIK ERATORRITAKO IKUSPUNTU JAKIN BATEK PROPOSATZEN DUEN IKUSMOLDEA; GURE EGUNEROKO OGIA}

Arte kontzeptualaren bilakaerak eta akzio publikodun artearenak objektuaren errepresentazioaren eta praktika jakin batzuk biltzen zein definitzen dituzten kategorien mugak lausotu eta difuminatu ditu. Termino klasikoetan, antologoak edota KK delakoak [Kudeatzaile Kulturalak] obra bat sortzen du 'antologatuak' izan behar duten kreatzaileak hautatzeko baldintzak eta aukeraketa bera proposatzen dituenean. [...] Antzinako gizarteek eta berriek ere, helburu dibertsoekin kultura bideratzeko eta zuzentzeko moduak bilatu zituzten; besteen artean eta txit goraipagarria izanik norbere botere-posizioa indartzearena, beroni goratzarre egiten zieten ekoizpen aberats baten elementu sinbolikoez baliatuz. (Tono Martínez, 2007: 67-68)

Optika konkretu batek panorama finkoak eta jakinak begi-bistara gerturatzen ditu. Deigarria dirudi nola goiko lerroetara ekarritako paradigmak (eta sarritan hauei loturiko aurreiritzi axiomatikoak) gaur bertan praktikatzen den arteari dagokion irakaskuntzan edo - kasu honetan eskulturan-, 
zuzen hala zeharka nahiz modu kontziente edo inkontzientean beraien ahotsa altxatzen duten, ikasgaien helburuetatik ikaskuntzaren neurtzaileetara, edukietatik trebetasun edo gaitasunetara, xede nagusitik galdera 'egituratzailera', ondorioetatik irakaskuntzaren emaitzetara, ariketetatik arazoen konponketa edo bideratze 'asertibora' eta irakasgaien programetatik irakaskuntza gidetara jauzia egien denean. Bistan denez, 'nomenkladura' bera Bolonia osteko egoerari dagokiona litzateke; lexiko berriaren katalizatzaileak nonahi izurtzen dituelarik egitura magmatikoak solido bihurtzeko 'tanta' miresgarriak. Jakin badaiteke gauzak ez direna egun batetik bestera aldatzen, baina aldaketaren grina biziak sugarra isioturik mantentzen duenean aldaketa bere 'naturaltasunean' ematen dela pentsarazi ahal dute.

Lehenagokoari ezin eutsiz eta datorren guztia ezin ongi erditurik dagoenean, eguneroko lanari behin baino gehiagotan originaltasuna ere antzematen zaion Arte Ederren Fakultatean (espainiar estatuko unibertsitate publiko arautuaren sisteman dagoen Euskal Herrikoa), batez ere eskultura alorreko bizpahiru irakasgaien kasuan zentratuko da arreta. Puntu honetan, gainera, bi parte desberdinduak proposatzen dira printzipioz. Alde batetik Arte Ederren Fakultateko Graduko ikasketetan eskultura arloak duen lehen ziklo komuneko tartea (Graduko lehendabiziko zikloaren enborreko bi ikasgaietan), eta bestetik Arte Graduko bigarren zikloko ikasgai berezi batek azken hamar urteetako eraldaketa prozesuan hartu duen forman. Guztiak ere jadanik Boloniako premisetara formalki moldatuak, lehenengo adibidean tradizioz Arte Ederren Fakultateko irakaskuntzak suposatu duen historian oraindino errotuagoak daudela argiro ikusiko da eta bigarren adibidea, ikaskuntza kooperatiboaren premisetara zuzentzen da.

\section{Eskultura I eta Eskultura II. Irakaskuntza praktiko teorikoa: arte-tailerra garaile?}

Artea, Sorkuntza eta Diseinua eta Kultura Ondareen Zaintza eta Zaharberritzea unibertsitate-gradu ofizialetako irakasgai komunak dira une honetan Eskultura I (lehen mailakoa) eta Eskultura II (bigarren mailakoa), Arte Ederren Fakultateak (UPV/EHU) eskaintzen dituen hiru graduetako aitzin biurtekoan eta administratibo zein akademikoki Eskultura Sailari dagozkionak. Aldaketak bitarteko, hasiera-hasieratik lan praktikoarekin (hau da, artearen aitzin-praxiarekin) erabateko kontaktua hartu behar dute ikasleek, ohiko ariketen planteamenduarekin. Arte-hezkuntzaren rol aktiboa unibertsitateko irakaskuntzan gelako eta tailerreko lan muinoan kokatzen da zentzu honetan. Besteak beste, materialez hornituriko lan eta ekoizpen plastikoaren izaeratik eratorriak diren halabeharrezko kontzeptu eskultorikoak asimilatu behar dituzte ikasleek. Kontzeptu horiek, halaber, abangoardiatik aurrera eskultura ulertzeko abian jarri ziren kategoria modernoei lotuak daude. Eskultura I lehenengo mailako enborreko (orain adarraren oina- 
rrizko) ikasgaian materiala bolumenean ulertzetik eskultura espazioan ulertzera doan ibilbidea jorratu behar dute ikasleek, ariketa praktiko oso zehatzen bitartez eta modu zuzenean osagai morfologikoetan gehien sakonduz (Kandinsky zenaren Puntua eta lerro planoan ekarpena adibide gisa). Akabuan espazioa bera eskulturaren lehengaia izan daitekeela ulertu behar dute, eta herri honetan hori ere neurri baten Jorge Oteizari sor zaiola ezin ahaztu.

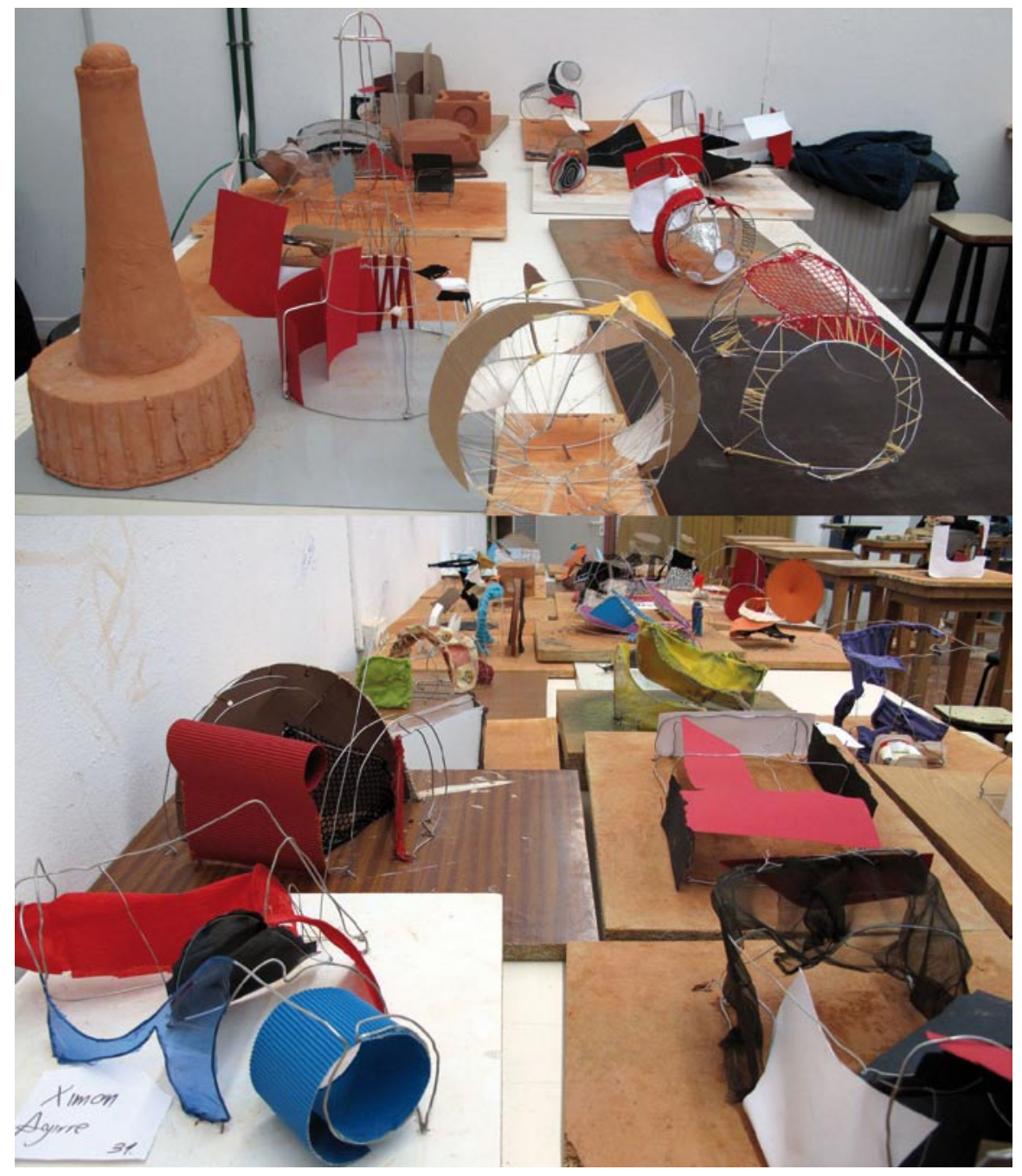

2. irudia

Kurtsoko lehen ariketa (buztinez modelaketa, objektu arruntaren eskala zein berezitasun aldaketan datzana) eta bigarren faseko gehigarriak: lerroa/planoa (2012-2013//2015-2016. urteak) 
Kontzeptuzko hitz-klabeen segidak (BOLUMENA, MASA, ESPAZIOA, LERROA, PLANOA, MODELOAREN BERRINTERPRETAZIOA, ESKALA, FORMATUA, PROPORTZIOA, ESTRUKTURA \{EGITURA\}, TAMAINA, HUSTUKETA, MATERIALAK), hiru dimentsioko konfigurazioaren elementuen jabe egitea eta kontzientzia izatea eragiten

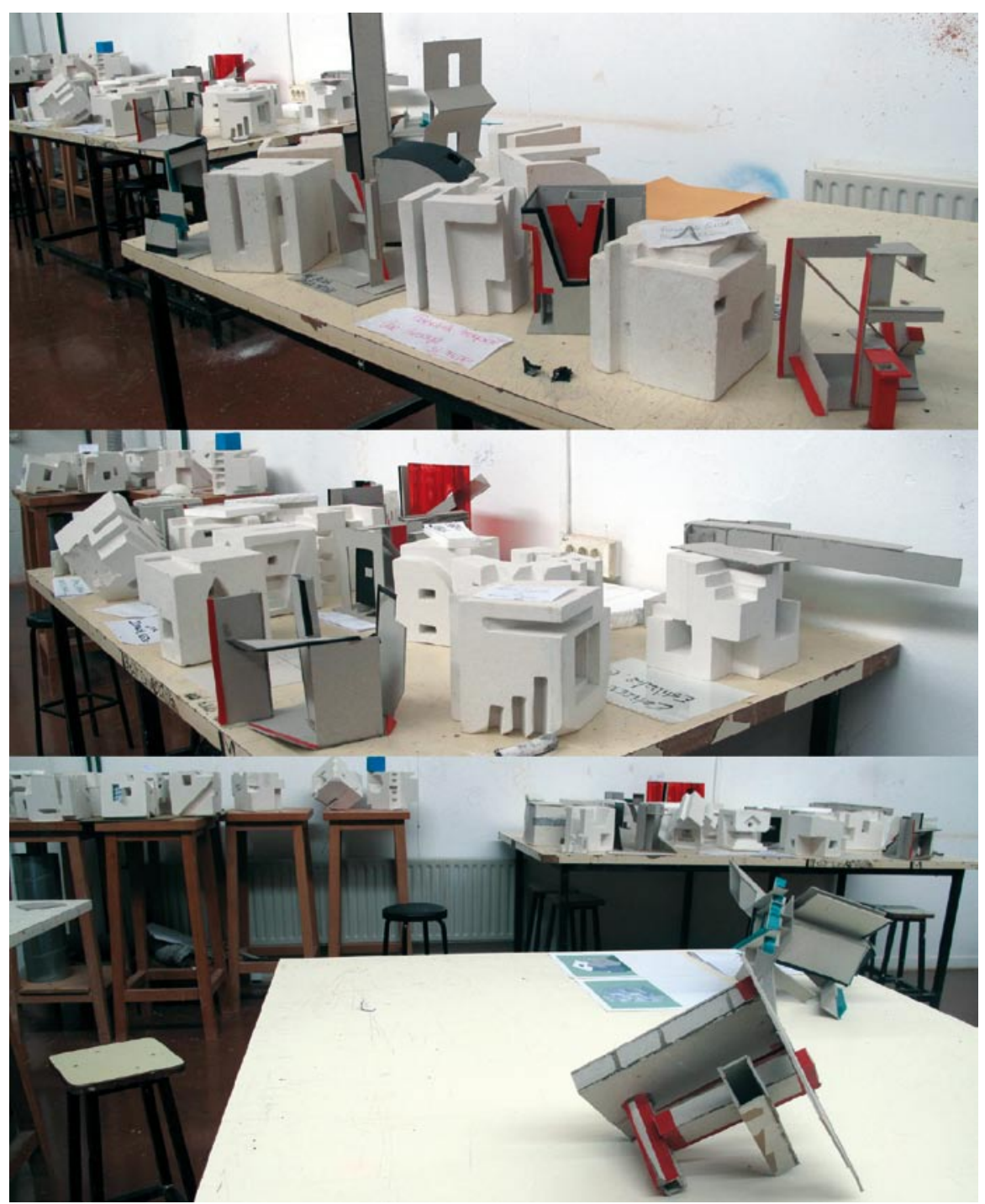

3. irudia

Kuboaren hustuketa, kurtsoko 2. ariketaren parteak eta aldaerak (2012-2013. ikasturtea) 


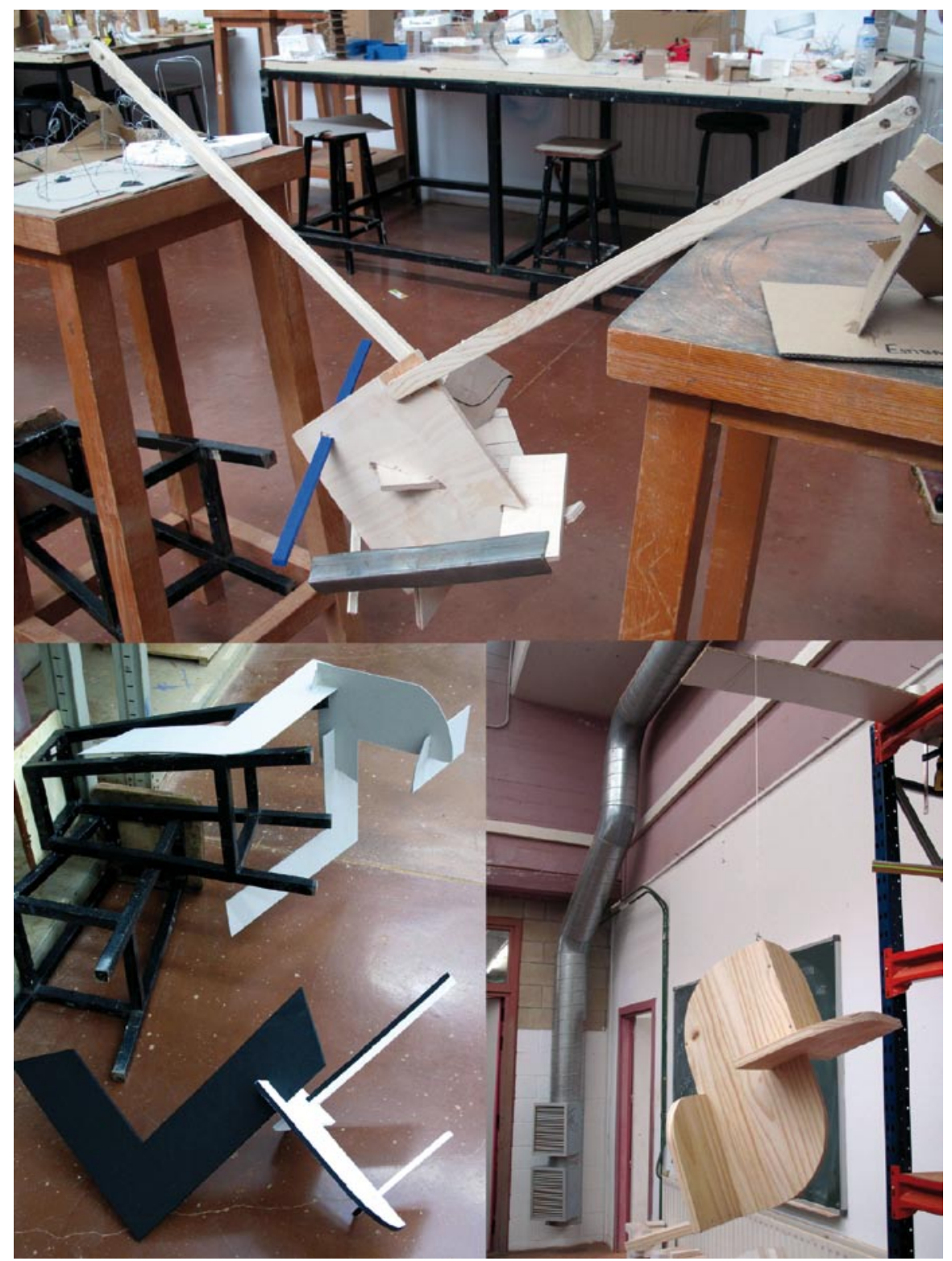

4. irudia

Kurtsoko azken ariketa, giza gorputzaren eta arkitekturaren morfologia abstraktua. Kokapena kontuan izanez eginiko saiakerak (2009-2010, 2012-2013 eta 2015-2016. ikasturteak) 
du, teknika eskultorikoa baldintzatzen duten zenbait prozeduraren bitartez: modelatzea, eraiketa, hustuketa, zulatzea, e. a. Antolaketa formalaren erreferente bezala artearen bilakaeran (eskulturan batik bat eta gehienetan Xx. mendeko abangoardietatik gaurdaino) izandako adibide eredugarriak aztertzen dira klase teorikoetan baina inoiz ez jarraitasun historiko soila opatuz, baizik tailerreko lan praktikoaren lagungarri izan daitezen aukeratuak. Honela, objektuak berak artelan bilakatzeko nola ingurumariko espazioarekin eta kokapenarekin erlazio koherenteak ere gauzatu behar dituen hasten dira ohartzen kurtso bukaera aldean, harreman topologikoen garrantzia azpimarratuz. Gaia osatzeko oinarrizko bibliografia irakurri arazten zaie ikasleei eskaturiko ikerketa lantxoaren aitzakiaz, hau ere ehuneko portzentaje altuan abangoardiako artisten beraien idatzietan oinarrituz, garai bateko arte-manifestuetan ezagutarazten ziren lerrokadura estetiko plastikoak goraipatuz (González; Calvo Serraller \& Marchan Fiz, 1979).

Eskultura II bigarren mailako nahitaezko ikasgaian (lehen zikloan eta gradu guztietakoa hau ere), Eskultura I irakasgaiaren jarraipena den heinean, honen izaera ere praktikoa eta teorikoa da, beti ere praxiari lehentasuna emanez. Lehen mailako oinarrizko kontzeptuak finkatzea eta sakontzea da honen helburua, apurka apurka eta kurtsoa aurrera doala irudikapenaren nozioa azalerazten hasten delarik. FORMA/ MATERIALTASUNA, TEKNIKA, ANTOLAKETA PLASTIKOA, MASA, ESPAZIOA, IRUDIKAPENA, IRUDIA, MIMESIA, eta EGITURA nozioetara testuen bitartez hurbilketa teorikoa egiteaz gain, eskulturaren praktikan antzematea eta aztertzea da ikasleek lortu beharreko jomuga, eskulturaren egite eremua praktikoa baita. Esanbeharra dago, eskultura irudikapen teknika gisa ulertzea eta aztertzeak, berezitasun propioak atxikitzea suposatzen duela. Ostera, ez da esan nahi aipaturiko nozioak eskultura arloan besterik ezin direla aplikatu; berez, arte-kategoriak direlako eta ikasleek horrela ulertu beharko lukete (lituzkete). Halere, egiazta daiteke, teknika bakoitzaren berezitasuna medio, ez dela gauza bera pintura bat edo eskultura bat gorpuztea; halanda ze teknikaren ezagutza ezinbestekoa da ikasleek diziplinartekotasunean murgiltzeko gaitasuna lortu ahal izateko. Arte-egitearen ezagutza (eskulturaren ezagutza) praktikan soilik ematen da, hau da, materiarekin harreman zuzenean; ez horrenbeste klase teoriko baten ondorioz, nahiz eta beharrezkoak izan gogoeta teorikoak pizteko eta praktikan sortzen diren arazoak nolabait izendatzeko. Zentzu honetan ohiko ikasketekin desberdintasunak ematen dira eta eskultura(ren) jakintza garatu ahal izateko, konpromezua, erabakiak hartzeko ausardia, lan autonomia, sormena, barne-behaketa, autokritikarako eta experimentaziorako jarrera berezia beharrezkoak dira, eta aldi berean experimentazio lan guztiek suposatzen duten porrotak onartzeko eta problematizatzeko kapazidadea.

Ikasgelan, testu teorikoak erabiltzetik aparte, artisten idazkiak arte praktikan oinarrituak, eta adibide praktikoak (eskulturak, pinturak, marraz- 
kiak, argazkiak, literatura eta filmeak) eskainiak izaten dira bailabide metodologikolez. Hauek guztiak bat egiten dute klase teorikoetan erabilitako eskemetan, zeinetan antolatu egiten dira adibide grafikoak, artisten idazkien atalak eta testu teorikoetan landutako nozioak. Honen guztiaren helburua ikasleek eskulturaren praktikarekin nolabait uztarturiko kontzeptuak bereganatzea da, batez ere praktikan izendatu ahal izateko.

Hala ere, teorian hain errez dirudiena, konplexu samar bihurtu egiten da praktikaren eta egitearen espazioan norbanakoa azpiratzen denean, teoria eta praktika uztartzea sarritan ezinezkoa baita. Artean ez dago formularik, ez dago ziurtasunik; beti asmatzen egon beharra irakasle-ikasleek onartu beharreko artearen izaera da.

Artikulu honek baliabide bezala aurkezten dituen eskema edota diagrama grafikoetan (1-6) konplexutasun hau azalarazi nahi da, hain zuzen. Horien segidak aurrenekotik hasita errepresentazioaren lilura ekartzen du gogora lehendabizi, eskulturak irudikapen teknika moduan duen oinarri sinbolikotik funtzionatzen baitu. Material bihurtze edo bilakatze prozesuan zehaztuz eta ukigarri zein dastagarri gisa duen fisikotasuna hutsunearen sentsazioarekin ere uztartuz, bere espazialtasun berezian. Tartean begiradak hartzen du arreta, baina delako begirada ere materiak eta formak espazioan duten jokaerarekin zentzu sinbolikoan gauzatuz. Baliabide plastikoen elementuek irudikapena posible egiteko sentsazioekin beste plano batean elkarlotura idoro beharko dute, batzutan ukiezina baina sentigarria izan daitekeen materialtasunaren bitartekaritza emozionalaz.

Erabili daitezkeen gaiak eta prozedurak distantzia batzuk erdiesten dituzte irudikatua izan behar duenaren eta errepresentazioaren beraren artean. Berriro ere begirada baldintzatuak egitura eraberritua eskainiko du, eraikitzailea den heinean. Horrela, gauzak eta objektuak 'berriz aurkeztuz' direlako errepresentazioak artearen praxian materialtasunetik (forma ematetik) datozen fenomeno sinbolikoak bailitzan ulertuko dira. Irudi horien funtzioak askotan mugakoak, limitekoak eta bitartekariak izango dira, edozelan ere, sinbolikoak izateaz gainera. Hortik aurrera subjektuak kontenplaziorako gaitasunaren bultzadaz eta sentitzeko inertziaren ondoriozko 'sentiberatasun artistiko' edo 'estetikoaz' jantzia, objektuak tximisten deskarga elektrikoak geldiarazteko mugarrien antzean barneratu ditzake. Izatez, objektuek 'karga' estetiko bermatua dute, baina berorrek ez du beti erradikala ez kontrakoa (katodiko hala anodikoa) izan behar; neutro izateagatik ere ez du botere izpirik galduko, 'bestaldeko lurraldeetan' leudekeen ideiazko toki-espazio ez-fisikoen erakarpenean.

Ikasgelan erabilitako eskemen adibide gisa hurrengo hauek aukeratu dira, baliabide metodologiko erara erabiltzeko ere txit lagungarriak diruditenak: 
TRANPA (Oteiza)

"Arte es trampa, artista es tramposo, hacedor de trampas" "He atrapado el motivo"..., " encierro en mi tela" (Cezanne)
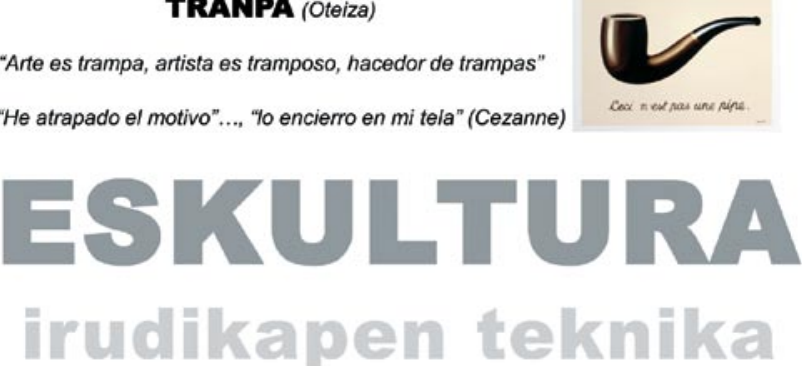

\section{Nolakoa?}

\section{FORMALA ETA MATERIALA}

1. eskema

Errepresentatu: ostera ere aurkeztu, mimesiarekin zerikusia dauka.

Agertu, altxatu. «Hau ez da pipa bat»; ez dauka pipa baten funtzio praktikoa. Pipa baten irudikapen piktorikoa da eta beraz, bere ezaugarria piktorikoak ez dira pipa erreal batenak. Eskultura ere, irudikapen teknika lez, ez da irudimenean ematen. Zertan datza arte-irudikapenak? harrapatze sinbolikoan

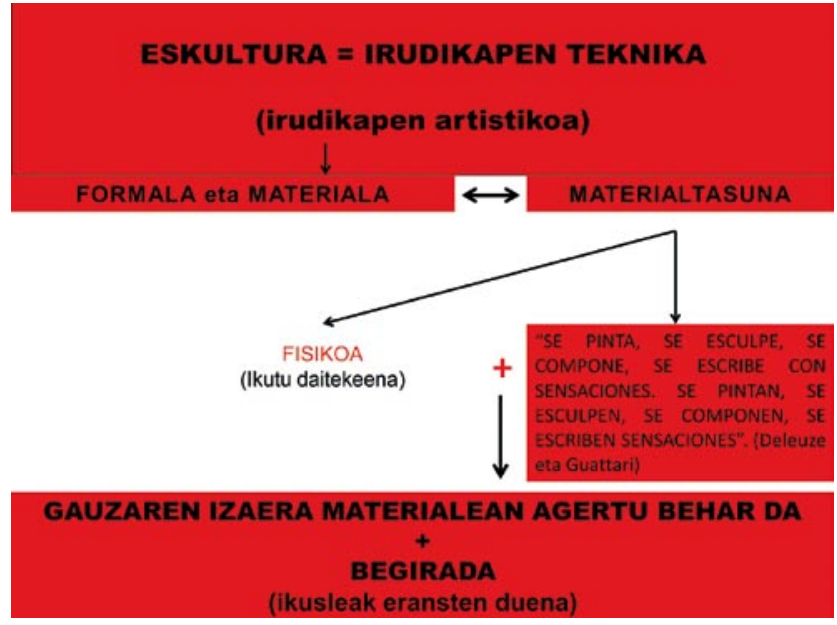

2. eskema

Fisikoa dena materialetan zehazten da eta sentsazioa hutsunean. Berau maiz espaziala da. Sentsazioa agertzen da begirada aktibatzen delako, prest dagoelako aurrean daukana jasotzeko. Aurre-disposizio ikasiarekin jokatuz eskulturaren teknika (artistikoak) materialtasunera jotzen du, materialaren eta formaren uztarketan (sinbolikoki) gorpuzten delarik, ikuslegoaren begiradapean 


\section{Irudikapen artistikoak \\ (Ekarpen sinbolikoak eta sentikorrak) \\ "Un eco perfecto" (Cezanne)}

“La sonrisa en el lienzo está hecha únicamente con colores, trazos, sombra y luz. ...personajes de pintura que respiran atmosfera de pintura" (Deleuze y Guattari)

\section{SENTIKORTASUN PLASTIKOA}

Emozioak materialtasunaren bitartez janzten dira

\section{BALIO PLASTIKOAK}

“Descubri que el sol no se podia reproducir, habia que representarlo por el color" (Cezanne)

"Para exteriorizarlo, intervendrá el oficio, ...(que) no tendrá mas pretensión que la de traducir (traer a presencia) inconscientemente por el pleno dominio de su lengua, ... la naturaleza vista, la naturaleza sentida, la que está ahí, la que está aquí, y ambas deben amalgamarse (mezclarse) para durar, para tener una vida mitad humana, mitad divina (espiritual), la vida del arte" (Cezanne)

\section{3. eskema}

Nola agertzen dira sentsazioak baliabide plastikoen bidez? Zeintzuk dira elementuak? Arte-irudikapenaren ekarpen sentiberak materialtasunaren bitartez emozionalki ematen direnean

"Hoy vemos el arte del pasado como nadie lo vio antes. Lo percibimos de un modo realmente distinto. ... Depende de nuestra posición en el tiempo y en el' espacio"

John Berger (Modos de ver)

\section{BEGIRADA ARTELANAREN ELEMENTU OSAGAIA, ERAIKITZAILEA ETA BERRITZAILEA DA}

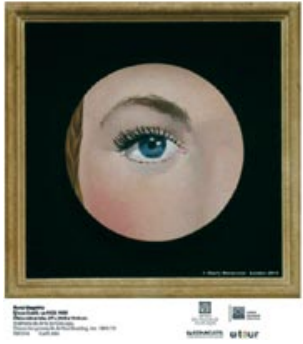

\section{BALDINTZATUA}

"Lo que sabemos afecta a
nuestro modo de mirar y a la
inversa lo que sabemos o
conocemos depende de
nuestro modo de mirar"

J. Berger

\section{4. eskema}

Errepresentazioaren markotik ikus daitekeen panorama.

Garaiaren eta distantziaren arabera begirada gaurkotu egiten du. Horrez gain, baldintzatua ere bada; egitura-emailea, eraikitzailea eta berritzailea izan daitekeen artearen praxitik destilatua 


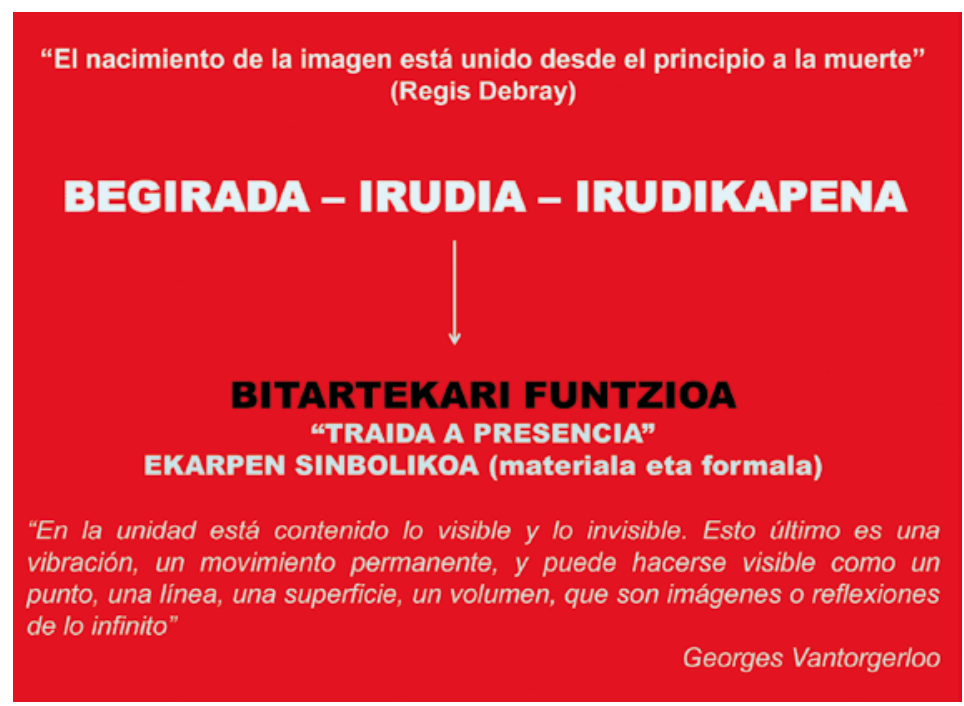

\title{
5. eskema
}

Irudikapena berriro aurkeztea da; beste modu batean aurkeztea. Honek zerikusi handia du begiradarekin eta 'irudiaren' bitartekari-funtzioan eragiten du, sinbolikoki gertatzen den errepresentazioari forma emateko, artearen materialtasunezko praktikari darion keinuaz

\section{IRUDIA}

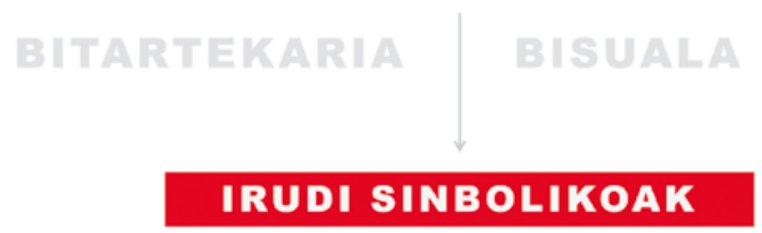

\begin{abstract}
"Las imágenes simbólicas, en definitiva, son formas intermediarias entre el' mundo interno y el externo; formas que no asocian las impresiones por caminos lógicos, sino mediante analogías sensoriales o vivenciales."
\end{abstract}

Manuel De Prada

\section{BEGIRADA $\longleftrightarrow$ SUBJEKTUA}

6. eskema

Orduan bitartekari-funtzioak betetzen dituzten irudiak sortzen dira eta baita propietate ikusgarriak bermatzen dituztenak. Arte irudiak, oro har, sinbolikoak dira. Bizipenak eta sentitzeko ahalmena subjektuan daude.

Beraz, objektutik kanpo agertzen dena, subjektuan inskribatzen da, bere baitan dagoelako; hau da, barneratuta daukalako 
Hala eta guztiz ere, delako eztabaidan honako puntu hau osatzeko zilegi dirudi ikasketen konfigurazio berrituan nola ematen diren, irakaskuntza gidaliburu ofizialetan, funtsezko ikasgai hauei egozten zaizkien 'deskribatzaileek' beregan hartzen dituzten eta definitzen dituzten trebetasun/ gaitasunak (konpetentziak):

\section{ESKULTURA I (E.I). Gaitasunak}

K1. Eskulturaren balioak, jakintza tekniko gisa, errealitatearen ikuskapenerako funtsezko egiturak eta alderdi 'anekdotikoak' bereizteko erabiltzea; honela, artearen elementu formal eta eratzaileen arteko beste erlazio modu batzuk egokituz eta deskubrituz.

K.2. Eskulturak erabiltzen dituen prozedurak eta materialen propietate berezkoak ezagutzeko sarbidea sustatzea, historian izandako eta egungo erabilerak aztertuz.

K.3. Materialtasuna, artelanaren (eskulturaren) muina den heinean, non subjektuaren 'signifikanteek' adierazkortasun bat aurki lezaketen (eduki oro materialtasunean bertan legokeenez), eskulturaren praxian duen potentziala ezagutzea.

K.4. Materialtasunaren gorpuzkeran bertan, irudiak, artearen zentzu bat eraikitzeko orduan dituen aurreiritziak antzematea eta eztabaidatzea, eskulturak, kultura-errepresentazioetan erabiltzen dituen eragiketa sinbolikoen bitartez kritikoki berraztertuz.

\section{ESKULTURA II (E.II). Gaitasunak}

K.1. Eskulturarekin enkontrua bideratzen duten nozioak, praxi materialean ezagutzea.

K.2. Eskulturaren jakintzarekin loturiko aurkikuntza pertsonal eta ebazpide materialen elkarketa bezala antzematea ikasketa teknikoa.

K.3. Eskultura esperimentazio ororekin bat datorren sinbolizatze edo zentzu ematearen funtsezko operazioa praktikaren bitartez ezagutzea (materialen, prozeduren, teknologien eta orokorrean eskulturari uztartuak dauden baliabideez).

* Iturria: Euskal Herriko Unibertsitateko (UPV/EHU) web orri eguneratuaren datu egokituak (Eskultura I, Eskultura II ikasgaietako irakaskuntza-gidak eta Arte Ederren Fakultateko Graduen zikloak/mailak. http://www.ehu.eus/eu/ web/vicer.grado-innovacion/aurtengo-graduak-arloa).

Trebetasun/gaitasun zerrenda honetako esaldiek testu honetako 2. puntuan aipatu diren lehenengo paradigmarekin dute erlazio estuena (premisa akademikotik eratorritako artearen irakaskuntza, artistaren tailerrean eskuraturiko jakintza eta modernitatean presentzia izan zuten eskolak). E.I eta E.II ikasgaietako K.1, K.2, K.3 eta K.4 gaitasunek eskulturaren dizipli- 
nari, trebezia teknikoari, material eta prozedurei zein 'materialtasun' kontzeptuari apelazio zuzena egiten diete. Uneren batean, subjektuaren adierazkortasuna (E.I, K.3) edota aurkikuntza pertsonala (E.II, K.2) bezalako adierazpen-esaldiek aurrerago laburtua izan den auto-adierazpenaren paradigmarekin zeharkako adierarik izan lezakete, baina ia beti eskulturaren praxiari eta praktika 'egokiaren' ikasketatik lortutako jabetzari so. Biak hala biak (E.I eta E.II), 3. mailako Arte Graduko Eskultura III ikasgairen sarrera direnak, edota gainontzeko graduetara doazen ikasleentzako hiru dimentsioko formaren/espazioaren ulerkortasunean eta saiakeran prestakuntza minimoa ematea zereginen artean dutenak.

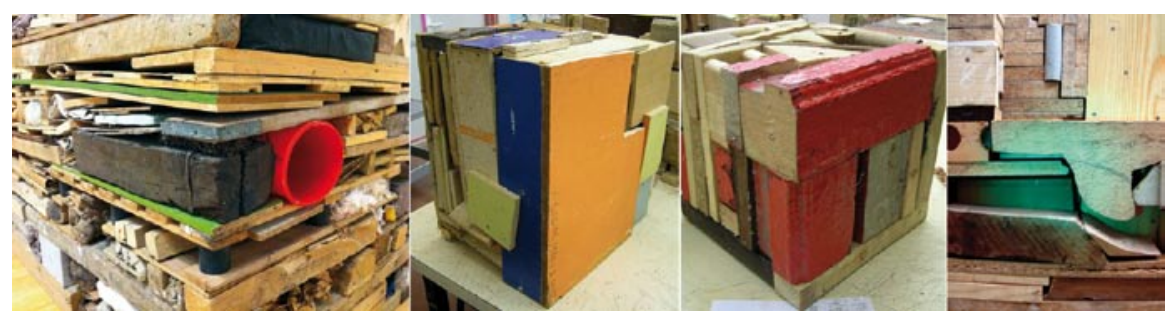

5. irudia

Tony Cragg, Stack (1975), kuboaren masifikazioa; ariketa osagarria (2008-2009. urtea).

\section{Eskultura, arkitektura eta hiri-paisaia edota Arkitektura eta hiri-paisaia eskultura formatuan. Irakaskuntza teoriko praktikoa: artearen baitako diskurtsoetan barne?}

Lau edo bost urtetik hona Eskultura, arkitektura eta hiri-paisaia ${ }^{9}$ titulua duen ikasgaiak ikaskuntza kooperatiboaren baitako (Domingo; Bará \& Valero, 2014) metodologia aktiboak aplikatzen ditu. Beraz, arazoetan oinarritutako irakaskuntzaren metodoa martxan jarri zen 2013-2014 ikasturtetik hasita, urte batzuez Arte Ederren Fakultatean behintzat fase esperimentalean izan den ERAGIN programaren bultzadaz ${ }^{10}$. Eskultura Sailak Arteko

9 1995-1996 urteko plangintzan agertu zen Arkitektura eta hiri-paisaia eskultura formatuan izenaz.

10 ERAGIN abizenaz ezaguna, Euskal Herriko Unibertsitateak (UPV/EHU) bere kalitatearen kudeaketa instituzionaletik (Errektoreordetza eta zentroetako kalitatearen dekanordetzak) martxan jarri duen irakasleen trebakuntzarako programa izan da. Ikaskuntza-irakaskuntza prozesuetan erabilgarriak izan daitezkeen baliabide berriak eskaintzen ditu, batez ere Ikaskuntza Kooperatiboaren metodologia aktiboena. Formaziorako plataforma honek urtero egin izan ditu deialdiak, bai proiektuetan, arazoetan eta kasuetan oinarritutako ikasketa Unibertsitatean gailentzeko esfortzuarekin. Arte Ederren Fakultatean oraindik ez dira izan irakasle asko deialdiren baten parte hartu dutenak, eta batez ere artearen jakintza arloen esparruan arazoetan oinarritutako ikaskuntza pribilegiatu izan da gehienbat. 
Graduko laugarren mailako ikasleei (bigarren zikloa) zuzentzen dien hautazko ikasgai honetan (Eskulturako 'Minor' delakoa osatzen duen ikasgaia izaki) lehenengoz \% 50ean aplikatu izan dira arazoetan oinarritutako metodologia aktiboak (ABP letra laburtzailez). Ondorioz, bai irakaslearen zein ikaslearen koadernoetan (Vivas, 2014) irakaskuntza-eskenatoki horren detaileak xehatzen dira hari zuzentzaile egitura-emailearen inguruko 'arazo' printzipalarekin artikulaturiko azpi-arazo edo bigarren mailako elementu osagarriekin ${ }^{11}$.

Irakasgai teoriko praktikoa, eskulturaren praxia arkitektura eta hiri paisaiarekin elkartzen dituena. Bere edukierak, sentiberazko pertzepzioan uztartutako begiradatik abiatuz, eskultura eta arkitekturaren arteko funtsezko interferentzietan kokatzen dira. Horrela eskala, proportzioak, mugak, hutsa, masa eta bolumenaren moduko kontzeptuak (Eskultura I ikasgai basikotik zein Eskultura II eta Eskultura IIItik datozenak sakonduz) era berezi batean funtzionatzen dute; bai objektu eskultorikoaren interpretazio arkitektonikoan, baita hiri paisaiaren edota arkitekturaren interpretazio eskultorikoan ${ }^{12}$. Hiriaren denborazko garapenak, guztiz ideologikoak (zentzu zabalean eta irekian) diren modelo eta esperientziak zentzumen anitzen sortzaile gisa, elkar hartuko dute proiektuan, eraikia (arkitektura) zein sinbolizatua (eskultura) izan den espazioan, nahiz bizitzan ematen diren espazialtasun anitzetan eta oroimenezko paisaietan.

Ariketak baino kasu honetan hobesten den jardueren sekuentziak hastapeneko galdera eta bigarren mailakoekin haria tenkatzen duen aktibitateen diseinua errespetatzen du, eta fase edo atal horietan guztietan ikasketa metodologia aktiboekin bat datozen lanak proposatzen dira; bai gelan burutzeko eta baita klase orduez kanpokoak ere. Bestalde, testuen irakurketa aktiboak (gaiaren nondik norakoari tinko eusten diotenak; eskultura publikoa, hiri-paisaia, espazio urbanoa, arkitektura, e. a.) eta norberaren bilaketa-prozesuek klase magistralak baino askozaz garrantzia handiagoa eskuratzen dute. Bai ekintzak aurrera eramateko eta baita gureganaturiko informazio ugaria asimilatzeko ere talde lana erabakigarria izaten da, irakasleak gida-funtzioa eta dinamizatze-funtzioak elkartuz. Ebaluazio jarraituak bai ikaslearen eta baita taldearen progresioa (garapen lez kontsi-

11 Planteatu arazoaren egiturazko galdekizuna honela formulatua izan zen: «Hiri-paisaiari, arkitekturari eta eskulturari dagozkion zein aspektu/elementuk parte-hartzen dute eta zeintzuk izan behar ditugu kontuan hiriko espazio publikoan obra artistiko eskultoriko baten kokapenean?» Iradokizun honek ikasgaiaren nondik norakoa modu osoro sintetikoan definitzen du, eta emaniko arrapostuak ikasgaiaren konplexutasuna bere horretan menderatzea esan nahiko luke. Irakurketa luzeegia ekiditeko honetan utziko da, baina ikasgaiaren programako zehaztasun guztiak jakiteko ikus bibliorafía (Vivas, 2014).

12 Nestor Basterretxea euskal eskulturagile handia zenak esana gogoan: «arkitektura jada nire eskulturan zegoen». Direkzio berean baina kontrako norantzan: «eskultura jada nire arkitekturan izan zitekeen» adieraziko zuen ziurrenik, Mies Van der Rohe abangoardiako arkitekto arrazionalista ospetsuak. 
deratua) oso kontuan izaten du (haserakoa, erdibidekoa eta amaierakoa), ikasketaren helburuen eta emaitzen artean gaitasunen (konpetentzien) lorpena presente edukiz; bai ikasgaiari bereziki atxiki zaizkionak, bai kurtsozikloaren baitakoak eta titulazioari dagozkion zeharkako trebetasunak ere.

Horien gainbegiraketa egiterakoan hondokoarekin erraz topo egin dezakegu:

\section{ESKULTURA, ARKITEKTURA ETA HIRI-PAISAIA (EAHP). Gaitasunak}

K.1. Monumentua, eskultura publikoa, estatua, basea edo euskarria ('peana'), eskala, tamaina, proportzioak, limitea, hutsunea, masa, bolumena eta espazioa bezalako terminoak finkatu eta zuzentasunez erabiltzeko gai izatea; bai eskulturaren interpretazio arkitektonikoetan eta baita hiri-paisaiaren zein arkitekturaren interpretazio eskultorikoetan tentsio bidez funtzionatzen dutenak.

K.2. Goiko paragrafoan oinarrituz, hiriko espazio publiko urbanoan kokaturiko artelan eskultoriko bati dagokion azterketa sintaktiko morfologiko eta semantikoan aipatu kontzeptuak identifikatzeko gaitasuna; proiektatua izan den planoaren espazialtasuna eraikitako ingurunearekin konektatzen duten pertzepziozko esperientzia sentikorrak eta harreman topologikoak lotzen dituela.

K.3. Testuinguru urbanoetan ematen diren planteamendu eskultorikoek lagungarri dituzten sinbolo eta zentzu-emate operazio basikoen ulermena, esperimentazio artistiko estetikoarekin eta indibiduoa/gizartea erlazioarekin bat datozenak, eragiketa horretatik artelan bat ondoriozta dadin.

K.4. Diziplinarteko proiektu artistikoak (eskultorikoak eta arkitektonikoak batik bat) ulertzeko, balioztatzeko eta planteatzeko konpetente izatea, hiri-paisaian eskultura publikoarekin, arkitekturarekin eta instalazio/kokatze dispositiboekin elkarlotuak leudekeenak, alegia.

K.5. Artea (eskultura) jakintza berezitu edota espezifiko gisa konprenitzea, espazio publikoan agertzen dituen adierak eta funtzioak ezagutuz, hiri-paisaiarekin eta arkitekturarekin integratzeko aukerak kontsideratu behar direnean ikuspuntu kritiko eta hausnarketazko bat posible egiteko.

** Iturria: Irakaslearen koadernotik euskaratua, arazoetan oinarritutako ikaskuntza kooperatiboa.

Gaitasun hauek zuzenki erlazioan doaz titulazioko beste zenbait trebetasunekin:

\section{ARTEKO GRADUA. Gaitasunak (orokorrak eta zeharkakoak)}

G1. Artearen jakintza teknikoa dela jakitea (zeharkakoa). 
G2. Sortzeko ekintzaren eta egindakoaren erantzukizuna bere gain hartzea (artista garaikideari sozialki eskatzen zaionarekiko), eta konpromisoa hartzeko gaitasuna edukitzea (orokorra).

G3. Egiteko dauden moduei eta artearen arloko lan-eremuei lotutako materialak, prozedurak, teknologiak eta, oro har, baliabideak erabiltzeko gaituta egotea, artearen berezko identitate eta leku-alderdietan moldatzeko (orokorra).

G6. Artearen diziplinetatik atera diren eta konfigurazio eta irudikapen-prozeduretan eragina duten oinarriak erabiltzea (orokorra).

G8. Gertaera artistikoen eta haien gizarte-testuinguruen arteko loturak ezagutzea, eta haien funtzio eta esanahiek artearen historiaren zein kultura garaikidearen inguruko ikuspuntu gogoetatsu eta kritikoa berdintasunaren, diskriminaziorik ezaren eta bakearen kulturaren balioak eskuratzeko duten garrantzia ulertzeko gaitasuna (zeharkakoa).

* Iturria: Euskal Herriko Unibertsitateko (UPV/EHU) web orri eguneratuaren datu egokituak. (Euskal Herriko Unibertsitatea (2015/2016). Arte Ederren Fakultateko Graduen zikloak/mailak. Irakaskuntza gidak: http://www.ehu.eus/eu/ web/vicer.grado-innovacion/aurtengo-graduak-arloa).

Era berena, Arteko Graduaren 4. mailako (2. zikloa) gaitasun batzuk eragiten dute:

\section{LAUGARREN MAILA (BIGARREN ZIKLOA). ARTEKO GRA- DUA. Gaitasunak}

C2. Artearen jakintza berezitu edo espezifikoarenganako konpromisoa. Artisten eta euren pentsaeraren ezagutza haien obra eta testuen bitartez.

C5. Jarduera artistikoan, gizartean propioak diren indibiduoa (-) kolektiboa harremanak identifikatzea. Sorkuntzaren akzioaz dagokigun errespontsabilitatea hartzea, artista garaikideari gizartean exijitu diezaiokegunaren arabera. Konpromisoak hartzeko eta lantzeko ahalmena.

C6. Esperimentazio artistiko orok, artelan baten ernaldu dadin daraman sinbolizatze operazio basikoa ezagutu eta aurrera eraman ahal izatea.

* Iturria: UPV/EHUko web orri eguneratuaren datu egokituak eta autoreak euskarara itzuliak (Euskal Herriko Unibertsitatea (2015/2016). Arte Ederren Fakultateko Graduen zikloak/mailak. Irakaskuntza gidak: http://www.ehu.eus/eu/ web/vicer.grado-innovacion/aurtengo-graduak-arloa).

Maila honetako ikasgaiak eta aipatu metodologiarekin prestaturikoak lehenago ikusi diren adibideez gaindi jakintza-arloaren berregituraketaren eta azken finean ikus kulturaren begiradetan agian trebatuagoak lira- 
teke. Honakoa aurkitu delarik batez ere gaitasunen izendapenean: irudien ikuspegi kritikoa eta gogoetazkoa (EAHP K.5, G.8), testuinguruaren eta indibiduoa kolektiboaren gizarte harremanak (G.8), esanahiak eta funtzio historikoak (G.8), artista garaikidearen konpromiso soziala (C.5), analisi sintaktiko, morfologiko eta semantikoak (EAHP K.2), sinbolizatzea eta zentzu eraldaketa (EAHP K.3, G.6); arte-alor berezituaz kanpoko beste jakintza-arlo edota diziplina humanistiko batzuei ere arrera berezia egiten dieten paradigmekin. Horiek guztiak, gaurko ikono-esferako irudiak irakurtzen jakiteko beharra ezin dute baztertu ${ }^{13}$.

\title{
4. PANORAMA DIDAKTIKO-PEDAGOGIKOAREN ALDAERAK ETA ERRONKAK GAUR EGUN ZEIN ETORKIZUN MEDIATIKOAN; ZERU OSKARBI BAINO BURU NAHASI
}

\begin{abstract}
'Proiektuaren' eta 'post-produkzioaren' artean jadanik ez dakigunean oso ondo non gelditzen den 'produkzioa' [...], dena bilakatzen da azkarazkar estereotipo, eta ez dugu bere arriskua nozitzen; erreala da nonbait, artearen hezkuntzan ukigarri egiten dena. Zinez eskertuko genituzke ikerketa lerro batzuk (misio hori eskatzen baitigu) bere auto-adierazpen nahiekin ikasleak zerbait egin ahal dezan. (Laspiur, 2000: 12-13)
\end{abstract}

Egungo (arte) akademia eraberrituetan, hau da, unibertsitateetako arte ederren fakultatetan edota goi-eskoletan, bai atzerriko zein inguruko aditu zenbaitek (Balbastre, 2010; Ramos, 2011-2012) Europatik abian jarritako dinamika pedagogikoak erruz eta koherentziaz kritikatzen dituzte: konpetentzietan oinarritzea, gelako orduak eta gelaz kanpokoak, ikaslearen lan pertsonala, berrikuntza, ustezko 'sormena' - inoiz ez ongi definitua - eta antzerako kategoriak, hain zuzen, eta ederki izendatuak baina nahiko eskas kateatuak iraultzen dira hezkuntzako dokumentu ofizialetatik 'panoplia' liturgiko gisara, hein baten ezagutzaren erraietatik askaturik 'konpetentzia' direlakoak gestionatzeko, baina pentsamenduaren kontzeptu beraren aurka doazenak. Honek guztiak unibertsitateetako hezkuntzaren paradigma berriak itxuratzen dituen arren, artearen heziketaren alorra nola aztoratu duten salatzen dute ${ }^{14}$.

13 Azterketa kualitatibo honetan datu zehatzik erabiltzen ez bada ere, unibertsitate-sisteman arte-hezkuntzako metodologia berrien aplikapenarekin bataz besteko ikasle-taldeen erdia sentituko zen eroso.

${ }^{14}$ Beharrizanok hezitzaileen (irakasleen) aukeraketan ere sano eragiten dutela adieraziko dute; dinamismoa, autoritatearen zentzu 'naturala' (galdera ikur handi bat jarriko zaio ez baita esanahia ongi harrapatzen), irmotasun/flexibilitate binomioa, izpirituzko 'irekiera' (beste galdera itzel bat mereziko luke; zer demontre da hori?), proiektuak gidatzeko kapazitatea zein berrikuntzarako sena eskatzen zaie. Hauek guztiak dira 'management' gaurkotuaren funtsak, sektore pribatuetan ematen diren erlazio sozialak imitatzeko intentzioarekin 
Izan ere, Boloniako itunetatik eratorritako estatuan estatuko plangintza europarrek hauts zaharrak astindu ez ezik modu argian Ipar Ameriketako Estatu Batuetako oinordekotza jaso dute; bai formalki eta baita ideologikoki ere nolabait, naiz eta Europako herrialdeetako berezitasunak oraindik orain erabat ezabatu ez diren. Kalitateari zuzenduriko jarraibideetan lehiakortasuna saritzen da (konpetente izatea - gai izatea - eta lehiakortasuna ez dira gauza bera) eta laneko produktibitateak bereganatzen du garrantzia gorena (nahiz eta batzutan kontrakoa dela zin egin). Irakaskuntzaren jardunean gestioaren printzipioak are eta teknokratikoagoa izan behar du ustezko denbora eta 'energia' (edozertarako balio duen beste hitz komodina) 'galtzeak' ekiditeko. Proiektu-eskemak, bide-orriak, modeloak, txantiloiak, galdeketak eta bestelakoak fabrikatzen dituen 'agentea' bihurtzen da irakaslea eta horrekin batera berrikuntza pedagogikoko 'managenent' erako ikastaroetara hurbiltzen den bakunenetakoa. Praxia bera merkatu ekonomiko globalaren eskakizunetara eta kontsumoaren gizarteko logikara egokitzen den errekurtso legez, jakintza gutxitua ateratzen da. Artearen esparru konkretuan, praxiak diskurtso garaikideetara duen egokitzapenean igartzen dira honako haize boladak. Aitzitik, artistaren izerdiak eta nekeak bestelakoak dira; artistak pentsatu ahal izateko 'produzitzen' du baina produktibitate hori ez da beti erabilgarria ez etekinak ('material-fisikoak') lortzekoa. Artegilearen 'produkzioa' (kakotx artean) materialtasunari kontu egitea eta materialtasun horretatik askaturiko indar-kemena zutik jartzean datza, inguratzen dituen espazio-lekuaz uneoro kontziente izanda. Artistarengan 'ekoizpena' ideiak materialtasunez aurkeztea da, izpirituzko ariketa batetik abiatuta; eragiketa horretan beti egongo delarik berrikuntza. Eta ongi egiten denean etekina kolektiboa izango da, baina ez materialki neurgarria edo teknologia-zientzien 'kalitate' bermatuan oinarritua.

Irakaskuntza-hezkuntza prozesu berrien zehar-lerroetan irakaslearen funtzioa ez da izango hainbeste gela-talde batek kolektiboki ikasketak menperatu ditzan ahalegintzea, baizik pertsonek (unibertsitateetako 'bezeroek' eta abar) indibidualki, tamalez, euren 'konpetenziak' garatu ditzaten saiatzea, bakoitza bere erritmora egokituz. Errentagarritasuna hazkuntza ekonomikoan jarria denean, 'managenemt' delako kontzeptuari lotuak ez doazen jakintza humanistikoak atzerako bidea edota be-interpretazioa jasaten dute prozesu ekonomikoek gizarte-errentagarritasuna arbuiatuz.

eta gerora, hezkuntza zentro bakoitzak enpresa-egitura onar dezan prestatuak. Lan-egitura horiek, historia nola errepikakorra den kuriosoa bada ere, eskulan eraldagarria behar dute erronka berriei lagungarri izateko. Lan-mundu oso kualifikatuaren aurrean langileria elementalagoaren beharra ere areagotzen du zerbitzuen merkatuak, 'konpetentzien' eskakizunak polarizatuz. Berezitasun gutxiko lanpostuek gaur egun konpetentzia mordoa eskatzen dituzte baina guztiak ere nahiko 'bigunak', leunak. Egoera hauek lirateke, urrenez urren, 'jakitearen' aldean 'konpetentziak' izatea sustatzen dutenak. 
Horretan ibiliz unibertsitateetan eta hezkuntzako goi erakundeetan (beste mailetan ere) humanitateen eta batez ere arteen heziketak kolokan agertzen dira, 'erabilgarriak' direlarik soilik beraien aplikagarritasunak beste diziplina batzuetan eragiten badu. Artea ez gizartearen beharrizan primarioetara baizik 'aisialdira' enfokatua dagoenean, 'lagungarria' den zerbait bilakatzen da baina inolaz ere premiazkoa. Askoz jota aipatu 'materialtasunarekin' baino testuarekin topo egin daiteke; testua eta testuingurua. Norbanakoaren eta gizartearen artean, humanitateen eta arteen betekizunak birformulatzen eta berrebaluatzen dira sorkuntza kritikoari baino dibertigarritasunari arreta handiagoa eskaintzeko manipulatuz. Artean erabiltzen diren programa kulturalek ere sarri askotan men egiten diote arteari atxikitako negozio turistikoekin (museoetako dendak lekuko) eta heziketa programek 'ikusi beharko litzatekeenaren' isla proposatzen dute erosoki. Galdera asko egitea zaila baizen desatsegina bihurtu daiteke eta horien erantzuna nekeza produkzio-negozioaren mesedetan gertatzen ez denean (sarrera ordaintzeak ere jada arte-kontsumoa adierazten baitu). Halako espazio berritzaile batzuk, halaber arte-hezkuntzari dedikatuak, museoez gain hirietako kultura-zentroak izaten dira sarri askotan (BilbaoArte, Tabakalera Kultura Garaikidearen Nazioarteko Zentroa, Uharte, Kalostra eta gure ingurumarian izendatu daitezkeenak). Maiz eraberritutako eraikinak edo berriak izaten dituzte kokaleku, eta komunikabideekin zein aspektu teknologiko 'mediatikoekin' erlazio erabakigarria. Artista gazte edo ez hain gazte, eragile kultural eta abarrei zuzenduak, akademiatik nahiz hezkuntza-sistema arautuaren sabeletik printzipioz eta izaeraz aldendutako edota kanpoko programak hobesten dituzte eta aldi berean praktika artistikora irekiak dauden formazio edo egoitza-espazioak mantentzen dituzte, artearen praxiari dagokionean bederen intentzio didaktiko-pedagogikoaren eta hausnarketaren arteko erdibidean:

Izan ere, artea aukera berriak irekitzeko erresistentzia gune bat baldin bada, interesatzen zaizkigun praktika pedagogikoak eragiten duten eztabaidak artikulatzea ahalbidetzen dutenak dira. Bizitzeko beste modu batzuk, beste gorpuztasun batzuk, beste harreman batzuk, beste instituzionalitate batzuk, beste ekoizpen mota batzuk... pentsatzeko eztabaidak, hau da, mundua modu alternatiboan ulertzeko aukera eskaintzen duten eztabaidak. [...] 'Kultura/espektakulua' bikote arriskutsutik ihes eginez. (Tabakalera, 2015-2016: 6)

Arte-praktika zuzena eta heziketa-sistemen arteko gurutzapenak abian jartzen dira metodologia eta lan nahiz sortze-prozesu anitzen bitartekaritzaz, batez ere hezkuntza-esparrutik zentro kulturalaren bizitzara doazen interferentziazko hariak josteko eta gune publikoan bultzaturiko interbentzioen bidez (espazio publikoaren pedagogia eta bertan sustraitzen diren erabilerak) sorkuntza garaikidean sakontzeko. Horrek guztiak espazio arki- 
tektonikoan bertan zedarritzen diren gaiak tratatzeko pasabidea baldintzatzen du askotan, beste mota batzuetako laborategiak (zinema adibidez) edo erakusketak baztertu gabe. Esku-hartze aktiboa eskatzen duten sesio dinamikoak izaten dira, ikaskuntzarako egoera aldakorrak posible eginez; jolasaren, elkarrizketaren, ikerketaren zein praktika artistiko garaikidearen mugetan. Muga horiek, alabaina, 'kultura/espektakuaren' artekoak noiz diren arretaz kontu egin beharko litzateke. Arduraz bitartekaritza-praktiken ardatz legez funtzionatzen dutenak, alegia, 'arteari' ia beti edo behintzat nahi baino gehiagotan 'eta' partikula gibelean gehitzen zaiolarik ('artea eta kultura', 'artea eta ekologia', 'artea eta zientzia', 'artea eta generoa'...). Aldiz, inoiz edo kasik inoiz ez da kontrakoa gertatzen ('ekonomia eta artea', 'gizartea eta artea', 'politika eta artea'...). Bitartekaritza zona horiek pentsamendua eta arrazoimena aktibatzeko lanabes bezala kontsideratzen dituzte erakunde hauek, bai 'kanpokoa' eta bai 'barneko' konfigurazioa ikuskatzea eta kuestionatzea planteatzen duten neurrian. Euren antolakuntza eta produkzio moduak guztiz presente izan behar dituzte horretarako, pedagogia alternatiboak 'arteaz' gelditu dena onartzen eta ezagutarazten duten bitartean.

\title{
5. ONDORIO ANTZEKOAK MAMITZEN; AKABUKO BURUTAPEN EDO BURUHAUSTE BATEN BATZUK DOITZEKO PREMIAZ
}

\author{
Barkatu eragozpenak, gizartearen hobekuntzan saiatzen ari gara. \\ Itxaropenaren Kanpamendua (esaldi anonimoa, Madril)
}

Beharbada burmuinari kea dariola, Boloniako 'saltsa' nahasia goritan zegoela etorri ziren buruhauste neketsuenak. Goian esan bezala, etekinari zuzendutako gaitasun/'konpetentziak' eta kalitate-adierazleez zeuden garunak blai, hauek bihurtzen dituztelarik gibelera begira dauden zientziaren aspektu humanistak gertuko probetxuaren eta erabilgarritasunaren argudiorik sendoenak (Nussbaum, 2010). Sistemaren kritikariek ohartzen zuten jakintza-ezagutza dinamikak berrikuntzaren eta 'konpetzentzien' eskuetan eroriz elementu kontzeptualek espazioa galduko zutela eragin praktikoen aldamenean. 'Espazio-galtze' delako horren afera artearentzat ere bada, orokorrean eta eskulturarentzat behinik behin (modu osoro partikularrean). Eskultura espazioaren teknika baita. Era berean, espazioaren kontrola nola gauzatzen den nabaritzen da eta soziologia, politika, beharbada hirigintza eta bertze arlo batzuetara jotzen da setati baizen lotsati, faltan botatzen den zuhurtzia 'akademikoaren' eskean. Horrenbestez, espazio fisikoaren mugapena eta ulerpena arkitektonikoa bezainbat eskultorikoa da, ez hainbeste zentzu soziokultural antropologikoan, estetikoan baino. Artearen teknika 
eta prozedurak, aitzitik, orotan dira praktikoak (praxian dautza beraien izen-izana), eta bertatik zailtasunez finkatzen dira kontzeptuak. Kontrakotasuna dirudien arren, heziketa-sistema berriek artearen erdigunean praxitik abiaturiko praktika tekniko hori ezkutatzen, desitxuratzen edo gutxitzen dute materialtasunaren bidez baino testu bidez eta diskurtso bidez atzematen diren kontzeptu-kategorien aurrean.

Irakasgaien irakaste-ikaste prozesua ikusi da zeregin praktikoak lehentasuna duen saioetan egituratzen dela; honen bitartez nozio teorikoak esperimentatuz. Irakasgaien helburu eta gaitasunak, teoria eta praktika tartekatzen duen irakaste metodologia aktibo batzuen bitartez eskuratzen direnez gero, ikasleriaren lan pertsonalaren banakako edo taldeko jarraipena eskatzen du. Metodologi eraginkorren aplikazioa irakaslearen beharren araberakoa izango da eta arazo eta proiektuetan batez ere oinarritzen $\mathrm{da}^{15}$. Kontzeptuzko euskarri basikoak aurkezpen teorikoetan planteatzen badira ere, praktikan erresolbitzen diren arazoetan aberasten dira kontzeptu horiek eta bertan plazaratzen dituzte zehaztasun enpirikoak, ikaslearen esperientzian integratuz.

Metodologia 'aktiboak' deritzanek, ez al dira betidanik erabili arte-irakaskuntzan? Posiblea litzateke arte-irakaskuntza metodologia aktibo barik? Artearen izaera 'problematizatze' horretan datza. Beraz, zer nolako berrikuntzak dakartzate metodologia aktiboak arte-hezkuntzan? Ez ote doa artearen izaeraren kontra metodologia horiek proposatzen dituzten klase motak, non dena neurtu egiten da portzentajetan? Artearen esentzia horrela transmititzea posible al da? Artean denborak ematen duen perspektiba eta ikaskuntza ezinbestekoa da. Horrelako plangintza batean zinez zaila egiten da artearen benetako esentzia transmititzea eta gutxiago ikasleen partetik bereganatzea.

Eskultura I oso ikasgai basikoa da, lehen oinarriaren porlana gogortasunez trinkotu behar duena. Eskultura II ere funtsezkoa da, eta bertan lehen mailatik datozen ikasleek aurrera pausuak eman behar dituzte; ez horrenbeste diskurtsoan edo kritikan baizik eskulturan materialtasunez artikulaturiko agerkarietan. Gero irakasle batzuk eta beste batzuk euren esperientziaren eta 'ulerkeraren' arabera (edo beraien usteari jarriki) alde batera edo bestera joko dute. Hika-mika horietan ez da hautsik gehiago harrotu nahi baina hastapeneko hipotesia nolabait konfirmatuz, ECTS kredituen Europako unibertsitate-sistema berriaren hondoan ohiko irakaskuntzaren - tradizioz jaso dugunaren - premisak eta (inertziazko) joerak badiraute, labur esanda irakaskuntza akademiko baizen modernotik datozen paradigmak oraindik zilegitasun osoa galdu barik. UPV/EHUko Arte Ederren Fakultateko bigarren zikloetan eta konkretuki berrikuntza metodologikoz hornitu

15 Alde honetatik goi-mailako arte-hezkuntza beti izan da aktiboa, kooperatiboa eta arazoetan sostengatua. 
den Eskultura, arkitektura eta hiri-paisaia ikasgaian (Arteko Gradua, laugarren maila), tailerreko praktikak bizitasuna galdu gabe, testuinguruaren azterketari eta begirada kritikoari gehiago erlazionaturiko aspektuek lekua irabazi dute, bai materiaren gaiaren eta baita ikasketa-sistemaren bultzadapean.

Bide batez arteak gaurko, atzoko eta biharko (etorkizuneko) erronkei aitzindari material sinbolikoa eskaintzen die, galdera ikur gorpuztua (maiz erretorikoa bada ere); sentsibilitatez eta imajinazioz mundu berriak zabalduz baina ez aldiz dagoenaren onarpen apalerako, gizakiaren barrenean dirauen ondoeza are eta gehiago asaldatzeko baino. Alde horretatik artea ez da ez lasaigarria ezta sendagarria ere. Ezen ur-tanta izoztuen zaparradak min egiten du, batik bat aurpegian jotzen duen txingorra baldin bada. Hasierako malko biguna trinkotu eta bihurtzen baita txit gogorra; 'abazuza', laster harri kozkorrezko kazkabar sano ozena eta zalapartatsua izango dena.

\begin{abstract}
If we start from the practice of art and experience in higher education in fine arts, specifically in the disciplinary field of sculpture, treat it as fundamental objective the possibility and channels of transmission of art. This happens once the curriculum Bologna in our context (Faculty of Fine Arts. UPV/EHU), reform that directly affects the perspective that time gives all learning based on the aesthetic experience from the practice of art introduced. As the body of content, we stopped on three main subjects: «Sculpture I», "Sculpture II» and «Sculpture, architecture and urban landscape». Subjects that share a similar methodology but manifests itself differently. This leads us to ask how point are effective current active methodologies and resources applied to education in the visual arts field of knowledge in which we can defend, as a hypothesis that the methods used in university system of artistic training provided they have been active.
\end{abstract}

Keywords: higher art education, contemporary art, plastic arts, sculpture, university-system.

Si partimos de la práctica del arte y de la experiencia en la enseñanza superior en bellas artes, concretamente en el campo disciplinario de la escultura, tratamos como objetivo fundamental la posibilidad 
y los cauces de la transmisión del arte. Esto sucede una vez introducido el plan de estudios Bolonia en nuestro contexto (Facultad de Bellas Artes. UPV/EHU), reforma que afecta directamente a la perspectiva que el tiempo aporta a todo aprendizaje basado en la experiencia estética, proveniente de la praxis del arte. Como cuerpo de contenidos, nos hemos detenido principalmente en tres asignaturas: "Escultura I», «Escultura II» y «Escultura, arquitectura y paisaje urbano». Materias que comparten una metodología similar pero que se manifiesta de forma diferente. Esto nos lleva a plantearnos hasta qué punto resultan eficaces las metodologías activas actuales y sus recursos aplicados a la educación de las artes plásticas, ámbito del conocimiento en el cual podemos defender, a modo de hipótesis, que los métodos utilizados en el sistema universitario de formación artística siempre han sido activos.

Palabras clave: enseñanza artística superior, arte contemporáneo, artes plásticas, escultura, sistema universitario.

Si nous partons de la pratique de l'art et de l'expérience dans l'enseignement supérieur en arts plastiques, en particulier dans le champ disciplinaire de la sculpture, on traite comme objectif fondamental la possibilité et les canaux de transmission de l'art. Cela se produit une fois que le programme de Bologne a été introduit dans notre contexte (Faculté des Beaux-Arts. UPV/EHU), réforme qui affecte directement le point de vue et la perspective que le temps donne à tout l'apprentissage basé sur l'expérience esthétique de la praxis de l'art. Comme corps du contenus, nous nous sommes arrêtés sur trois sujets principaux: «Sculpture I», «Sculpture II» et «La sculpture, l'architecture et le paysage urbain». Matériaux qui partagent une méthodologie similaire, mais laquelle se manifeste différemment. Cela nous amène à se demander jusqu'à quel point sont-elles efficaces des méthodes actives actuelles et les ressources appliquées à l'éducation des arts visuels, domaine de la connaissance dans laquelle nous pouvons défendre, comme une hypothèse de travail, que les méthodes utilisées dans le système universitaire de formation artistique, ils ont toujours été actifs.

Mots-clé: enseignement artistique supérieur, art contemporain, plastic arts, sculpture, système universitaire. 


\section{ERABILITAKO ERREFERENTZIAK}

Agirre, I. (2002). «En la encrucijada», Cuadernos de Pedagogía, 311.

Arnheim, R. (1962). Arte y percepción visual, E.U.D.B.A., Buenos Aires: Alianza. Balbastre, G. (2010). «Feu sur les enseignants», Le Monde Diplomatique, 679.

Brown, T. (2011). «Haz lo propio», in: Zenbait autore (2011). En torno a la investigación artística. Pensar y enseñar arte: entre la práctica y la especulación teórica (87-102. orr.), Bellaterra, Bartzelona: Museu d'Art Contemporani de Barcelona (MACBA), Universitat Autònoma de Barcelona.

Camnitzer, L. (2013). Diálogos/Entrevistas: «En cierto modo sí, voy a dejar de hacer arte» (J.J. Santos eta R. Castilloren partez). Artishock. Revista de Arte Contemporáneo, 2013ko ekainaren 18a. http://www.artishock.cl/2013/06/18/ luis-camnitzer. 2015eko abenduaren 30ean kontsultatua.

Domingo, J.; Bará, J. \& Valero, M. (2013). Técnicas de Aprendizaje Cooperativo (hezkuntza tailerraren koadernoa), Donostia: Universitat Politècnica de Catalunya.

Echevarría, G. (2011). «There is plenty of room at the bottom», in: Zenbait autore (2011). En torno a la investigación artística. Pensar y enseñar arte: entre la práctica y la especulación teórica (45-58. orr.), Bellaterra, Bartzelona: Museu d'Art Contemporani de Barcelona (MACBA), Universitat Autònoma de Barcelona.

Euskal Herriko Unibertsitatea (2015/2016). Eskultura I, Eskultura II ikasgaietako irakaskuntza-gidak eta Arte Ederren Fakultateko Graduen zikloak/mailak. http://www .ehu .eus/eu/web/vicer.grado-innovacion/aurtengo-graduak-arloa.

Gamarra, G. (2012). «Las ciudades en Euskadi. La urbanización de la CAPV», in: zenbait autore (2012). Euskal Hiria: reflexión sobre la ciudad y las ciudades vascas (65-103. orr.), Bilbo: exJ-Liburuak.

González, A.; Calvo Serraller, F. \& Marchan Fiz, S. (1979). Escritos de arte de vanguardia 1900-1945, Madril: Turner.

Hernández, F. (2002). «Repensar la educación de las artes visuales», Cuadernos de Pedagogía, 311, 52-55.

Kandinsky, V. (1996). Elementu piktorikoei ekarpena. Puntua eta lerroa planoan, Donostia: Gaiak.

Laspiur, A. (2000). «Lo que nos hace seguir girando (en torno al arte)», in: Giróvago (erakusketaren katalogoa), Iruñea: Iruñeako Udala.

Lekerikabeaskoa, A. (2015). Encuentros y desencuentros entre los objetos provenientes de la escultura y del diseño en los espacios limítrofes y territorios híbridos (doktorego tesia), Eskultura Saila, Arte Ederren Fakultatea, Euskal Herriko Unibertsitatea (UPV/EHU): Bilbo (argitaratzeke).

Lowenfeld, V. (2008). Desarrollo de la capacidad intelectual y creativa, Síntesis: Madril.

Nussbaum, M. (2010). «Où va l' Université?», Courrier International, 1025.

Oteiza, J. (2007). Quousque tandem...! Euskal arimaren ulerkera estetikorako saioa (edizio elebiduna), Nafarroa (Iruñea): Jorge Oteiza Fundazio Muesoa.

Ramos, A. (2011-2012). «Innovación o competencias contra el saber», Fabrikart. Arte, tecnología, Industria, Sociedad, 10 ('Innovación/Innovation/Berrikuntza'), 202-213. 
Sauras, J. (2006). La enseñanza del arte (tradición, academicismo, magisterio y modernidad formativa), Real Academia de Nobles y Bellas Artes de San Luis de Zaragoza, Zaragoza (sarrerako hitzaldia).

Smithson, R. (2009). Robert Smithson. Selección de escritos, Alias: toki gabea.

Tabakalera. Kultura Garaikidearen Nazioarteko Zentroa (2015/2016). Hezkuntza programa de mediación 2015/2016. Donostia-San Sebastián: www.tabakalera. eus.

Tono Martínez, J. (2007). Conceptos y experiencias de la gestión cultural, Kultura Ministeritza: Madril.

Vivas, I. (2014). «Aprendizaje basado en problemas y aprendizaje cooperativo. Propuesta docente de la asignatura: «Escultura, arquitectura y paisaje urbano» (Cuaderno del Docente eta Cuaderno del Estudiante)», in: IKD-BA$L I A B I D E A K$, 8. zka. Euskal Herriko Univertsitatea. www.ehu.eus/es/web/ ikdbaliabideak/home.

Vivas, I. (2007). «Arte hezkuntza utopiaren eta pragmatismoaren artean», Tantak, $38,81-134$.

\section{Irudien eta eskemen jatorria}

1. irudia. Internet saretik (goian/erdian) eta Isusko Vivasen argazkiak (behean).

2-4. irudiak. Isusko Vivasen argazkiak (argitaratu gabeak).

5. irudia. Internet saretik (ezkerrekoa) eta Isusko Vivasen argazkiak (erdikoak/ eskuinekoak).

1-6 eskemak. Amaia Lekerikabeaskoa (2015). Encuentros y desencuentros entre los objetos provenientes de la escultura y del diseño en los espacios limítrofes y territorios híbridos (doktorego tesia), Eskultura Saila, Arte Ederren Fakultatea, Euskal Herriko Unibertsitatea (UPV/EHU), Bilbo (argitaratzeke), Bigarren Partea, II-77 / II-82. orr. 